Rev. Hist., N²8, vol. 1, Enero-Junio 2021: 36-73

ISSN 0717-8832

https://doi.org/10.29393/RH28-3CSSG10003

\title{
El cateador y el salitre. El cantón Lagunas: desde su descubrimiento hasta su industrialización (1850-1890)*
}

\author{
The "cateador" and saltpeter. The Lagunas canton: from its discovery to its \\ industrialization (1850-1890).
}

Sergio González Miranda**

\section{RESUMEN}

En este artículo se analiza, a partir del descubrimiento de "mantos de caliche" o "criaderos de salitre" en las pampas más australes de la provincia de Tarapacá, el proceso que llevó a la conformación de un cantón salitrero llamado "Lagunas". Ese territorio, que se conocerá con el nombre de "Lagunas", fue cateado a mediados del siglo XIX, constituyéndose en un cantón en la década de 1870, alcanzando su plenitud industrial en la década de 1890 con las oficinas salitreras South, Central y North Lagunas, más el pueblo y estación ferroviaria "Lagunas". Se destaca el papel clave del "cateador" y del "descubridor" -en esa etapa previa a la implantación de una oficina salitrera- a través de la biografía de Asencio Almonte de la Fuente, descubridor de "Lagunas". Se describe cómo se realizaron los primeros cateos, los pedimentos de estacas y la formación de sociedades para la explotación del nitrato de soda.

Palabras clave: Nitrato de soda, descubrimiento minero, cantón salitrero, desierto de Atacama.

\section{ABSTRACT}

In this article the process that made up a nitrate canton called "Lagunas" is analyzed from the discovery of "mantos de caliche" or "criaderos caliche" in the most austral pampas of the Tarapaca province. That territory, that will be known as "Lagunas", was prospected in the middle of the nineteenth century, being made up a canton in the decade of 1870, reaching its industrial peak in the decade of 1890 with the saltpeter offices South, Central, and North Lagunas, plus the town and railway station "Lagunas". The key role of the "cateador" or "discoverer" is highlighted -in that period before introducing a saltpeter officethrough the biography of Asencio Almonte de la Fuente, discoverer of "Lagunas". It is described how the first explorations were made, requests of stakes, and the creation of societies to exploit sodium nitrate.

Keywords: sodium nitrate, mining discovery, nitrate canton, Atacama Desert

Recibido: febrero 2021

Aceptado: mayo 2021

\footnotetext{
* Este artículo es resultado del proyecto Fondecyt Regular N 1190303. Mis agradecimientos a mi colega Luis Castro por su generosidad al facilitar fuentes documentales y a mis ayudantes José Alflorino Torres y Ronald Gutiérrez por la valiosa colaboración.

${ }^{* *}$ Sociólogo por la Universidad de Chile, Dr. en Estudios Americanos por la Universidad de Santiago. Investigador del Instituto de Altos Estudios de la Universidad de Tarapacá, Chile. ORCID: http://orcid.org/0000-0002-6934-4317. Correo electrónico: pampino50@gmail.com.
} 


\section{Introducción}

La industria del salitre atrajo la mirada preferentemente hacia la máquina ${ }^{1}$, la que emergió a mediados del siglo XIX, alcanzando su consolidación en la década de 1870. La máquina fue la atracción como lo demuestran las primeras fotografías que, como lo confirma Margarita Alvarado, permitían contemplar "la época del esplendor y riqueza, las chimeneas humeando, los obreros trabajando en las faenas, máquinas en movimiento, cuando todo era producción y energía" ${ }^{\prime 2}$. Uno de los primeros fotógrafos que registraron la actividad de la minería del salitre fue William L. Oliver, quien muy joven estuvo en Iquique el año 1863, cuando comenzaba lentamente a consolidarse esta industria gracias a las máquinas de vapor ${ }^{3}$. A partir de entonces la atención de centró en la tecnología, tanto por parte de los propios empresarios salitreros como por los viajeros que llegaron atraídos por esta industria, como William Mac Coy Castle, capitán de la Royal Navy, en 1883, y William Howard Russell, uno de los periodistas ingleses más prestigiosos de su época, en $1889^{4}$.

Este asombro por la tecnología en el desierto ocultó, en cierta forma, los procesos técnicos previos de lixiviación del nitrato, incluyendo las etapas de prospección del mineral que, en su estado natural, era conocido como "caliche". Los ingenieros y químicos lentamente reemplazaron a los cateadores, correctores, cortadores de yodo y maestros. Los saberes prácticos venidos de la minería colonial de la plata comenzaron a ser desplazados por la ciencia y la técnica modernas. Sin embargo, la importancia del cateador fue muy importante hasta 1868 , año en que se prohibió el cateo libre. Este oficio fue clave no solo para el descubrimiento de los mantos de caliche o "criaderos de salitre", sino también para el surgimiento de oficinas, pueblos y cantones salitreros.

Este trabajo, a través de un estudio de caso (de un cateador y su relación con una pampa, una oficina y un cantón salitreros), pretende ilustrar el proceso de industrialización mencionado y el consiguiente ordenamiento territorial del desierto salitrero de la provincia de Tarapacá. Sin pretender enmarcarse en el campo propio de la microhistoria, en cierta forma fue un trabajo de construcción cultural de un sujeto y su contexto histórico, por lo mismo, los documentos fueron considerados solo como informaciones parciales que, al pesquisar diversas fuentes, permitieron develar el fenómeno estudiado. El cruce de estas fuentes permitió estructurar un relato consistente sobre el sujeto investigado, sus actividades mineras, sus relaciones sociales

\footnotetext{
${ }^{1}$ González, Sergio. 2005“La crítica a la máquina surgida durante el ciclo del salitre”, en Revista Diálogo Andino №21, Arica, pp. 125-131.

${ }^{2}$ Alvarado, Margarita 2002. "La imagen de lo no vivido. Memoria y fotografía de las salitreras del norte de Chile", en Revista Aisthesis, №35, Santiago, 41-49, p. 49.

3 Jara, Álvaro 1973.Chile en 1860. William L. Oliver: un precursor de la fotografía. Editorial Universitaria, Santiago, p. 31.

${ }^{4}$ Bravo, Pedro. y González, Sergio. 1994. Iquique y la pampa. Relaciones de corsarios, viajeros e investigadores 15001930, Iquique, Ediciones TER.
} 
y familiares, su mentalidad empresarial, etc., con el propósito de construir un tipo ideal de cateador que devino en empresario salitrero quien, además, pertenecía a una de las familias tarapaqueñas de prosapia minera.

\section{La imagen del cateador}

La Máquina asombró a los primeros poetas del salitre, como fue el caso de Clodomiro Castro, quien en 1896 publicó su poema "Las Pampas Salitreras", donde le canta a la máquina más que al desierto y sus habitantes, como afirma José Antonio González, sería: "el primer homenaje a la industria en las letras chilenas" ${ }^{\prime \prime}$. El periodo de expansión de esta industria, caracterizado por administradores, contadores, ingenieros, químicos, mecánicos y técnicos, dejó atrás a los oficios mineros del largo periodo preindustrial de las oficinas de Paradas, caracterizadas por una baja escala de producción y redes familiares. En esa época el personaje más admirado fue el "cateador". El siguiente fragmento de un poema del principal poeta del norte grande, Andrés Sabella, trata la figura de este minero:

"iYo soy el cateador! Conozco el sabor de la sorpresa y tuteo el azar. Como charqui y polvo de amargos derroteros; bebo mi sorbo de agua mezclado con lágrimas y sudores. Mis ojos crecen, crecen, crecen hasta llenar el horizonte. iYo soy el cateador, hombre de cuatro rumbos y cuarenta cóndores despiertos en medio del instinto!" ${ }^{6}$.

El cateador fue imprescindible en este tipo de minería porque el salitre (o más bien el "caliche"7) estaba localizado en el subsuelo en mantos aleatorios a lo largo del amplio territorio desértico, con escasas rutas, carencia de pozos de agua y contados asentamientos humanos. En las décadas entre 1810 y 1850 la búsqueda de salitre tuvo más de aventura que de empresa. A pesar de ello, se cateó en territorios al norte del río Camarones y al sur del río Loa, sin saber los resultados. Posteriormente, por ensayo y error, se estableció que la existencia de salitre industrializable se enmarcaba entre la quebrada de Tiliviche por el norte y la de Taltal por el sur.

Las primeras pampas que fueron descubiertas y que contenían "criaderos de salitre" de alta ley, estaban ubicadas al interior del puerto de Pisagua y en las proximidades del bosque de Zapiga. Lentamente, en las décadas siguientes, se fue ampliando a todo el territorio comprendido entre la quebrada de Tiliviche y los cerros de Pintados. Las pampas más al sur de la provincia no quedaron fuera del interés y esfuerzo minero de los cateadores tarapaqueños, pero ofrecían mayores dificultades debido a la hostilidad del desierto y a la presencia de

\footnotetext{
${ }^{5}$ González, José Antonio. 1983.“Breve bosquejo de la pampa y el hombre nortino en la literatura chilena”, en Anales de literatura hispanoamericana $\mathrm{N}^{\circ} 12$, Madrid, pp. 81-97.

${ }^{6}$ Sabella, Andrés. Hombre de cuatro rumbos. Editorial Nascimento, Santiago, 1978, p.46.

${ }^{7}$ El término que se refiere a la materia prima que contiene sales y substancias en la que predomina el salitre.
} 
grandes salares. El poblado de Huantacondo, era el mejor lugar desde donde iniciar las campañas hacia esa fracción del desierto de Tarapacá (ver mapa 1), en busca de los esquivos "mantos de caliche" o "criaderos de salitre". En esas pampas solo el bosque de la Soledad ${ }^{8}$ y Quillagua ${ }^{9}$ podían ofrecer refugio temporal a esos aventureros y temerarios mineros.

En trabajos anteriores, hemos discutido acerca de la conformación de los cantones salitreros en el desierto de Atacama durante el ciclo de la industria del nitrato de soda ${ }^{10}$, sin embargo, no hemos analizado en detalle -a través de un caso específico- cómo se inicia y desarrolla este fenómeno minero.

Desde que comenzaba el cateo, los mineros salitreros debían establecer puntos en el desierto que fueran referencias entendibles para las autoridades, con el propósito de evitar pedimentos en territorios donde ya habían sido adjudicados "estacamentos" ${ }^{11}$. Esos puntos se basaban generalmente en características geográficas, pero después requerían se les asociara un nombre, que solía ser tomado de la toponimia existente.

Esos "puntos" generalmente fueron "nombrados" por el "descubridor", y ese momento no tenían otra función que la georreferencia para la autoridad (Diputación de minería o Subprefectura) y para ellos mismos, los mineros. Muchos de esos nombres con el tiempo fueron olvidados o reemplazados por otros. Hubo algunos que permanecieron y que se conservan hasta la actualidad. Ello aconteció cuando el nombre de un "punto" fue utilizado para designar primero a un pampa y luego a un cantón. En ese caso el nombre revelado por el "descubridor" pasó a formar parte no solo del ordenamiento territorial político-administrativo, sino también del habla cotidiana y de la cosmovisión pampinas. Ese fue el caso de "Lagunas".

La técnica minera que se empleó a partir del cateo fue lo que se conoce como minería "a rajo abierto" 12 , que para el caso salitrero se conoció con el nombre de "calicheras". Durante el periodo industrial, esta técnica minera "a cielo abierto" empleó líneas de explosivos en la superficie para extraer el material mineralizado, que se conoció como "tronaduras", para posteriormente acopiarlo, cargarlo y transportarlo. En la última etapa del ciclo de expansión de

\footnotetext{
8 Zolezzi, Mario. 1993. "Pampa del tamarugal. La destrucción del monte de la soledad (ciclo salitrero)", en Revista Camanchaca, $\mathrm{N}^{\circ} 14$, Iquique, p. 6.

${ }^{9}$ Carmona, Javier. 2018. “Alfalfa y minería en el desierto surandino”, Revista chilena de Antropología №37, pp. $213-$ 229.

${ }^{10}$ González, Sergio. 2013. "Heterotopía y utopía en la pampa salitrera. Desde los mitos de la ocupación del desierto y del descubrimiento del salitre a la urbanización de la pampa, 1870-1920", en González, Sergio. 2013.La Sociedad del Salitre. Protagonistas, migraciones, cultura urbana y espacios públicos, Santiago, RIL Editores, 315-338. González, Sergio y Artaza, Pablo. 2013. "El concepto de cantón salitrero y su funcionalidad social, territorial y administrativa: los casos de Zapiga, Lagunas y el Toco", en González, Sergio. La Sociedad del Salitre. Protagonistas, migraciones, cultura urbana y espacios públicos, Santiago, RIL Editores, pp. 325-365.

${ }^{11}$ Los pedimentos mineros se realizaban con la "estaca peruana" como unidad de medida, que correspondía a 200 varas cuadradas.

12 Si bien hubo extracción de caliche de por medio de cuevas e incluso existió el oficio de "cuevero", fueron en pampas muy específicas, por lo que se puede afirmar que fueron excepcionales.
} 
la industria del salitre se emplearon diversas tecnologías para el carguío y transporte como ferrocarriles aéreos y terrestres, camiones y palas mecánicas. La escala de esta explotación de la naturaleza provocó un daño ambiental que aún se puede observar en el desierto. En cambio, durante el periodo preindustrial, conocido como "de las Paradas", el fenómeno fue distinto, hubo -por la escala de la explotación- mayor armonía entre naturaleza, trabajo y tecnología ${ }^{13}$.

En el Gráfico 1 vemos el cambio de la escala de producción a partir de la década de 1870. Hasta la década de 1860 la provincia de Tarapacá era prácticamente la exclusiva exportadora de salitre, solo una compañía se encontraba operando en esa década en Antofagasta ${ }^{14}$.

Gráfico 1

Exportación de salitre en toneladas métricas. 1830-1920.

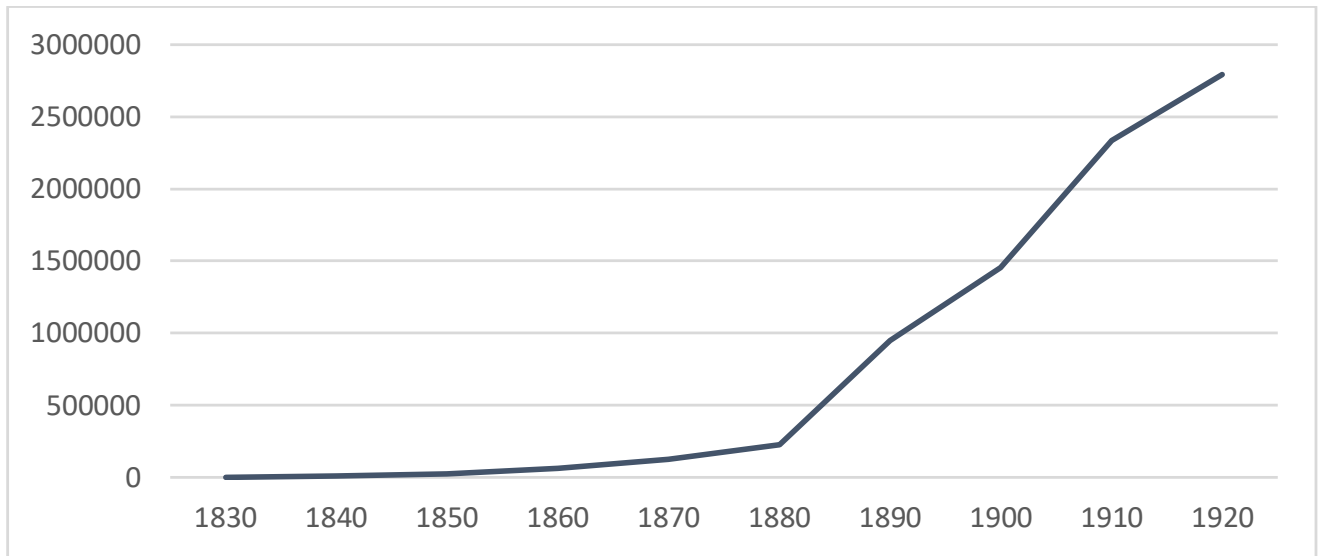

Fuente: Hernández, Roberto. El Salitre. Resumen histórico desde su descubrimiento y explotación. Imprenta Fisher Hnos., Valparaíso, 1930, p.174.

Durante el periodo de Paradas el momento más crítico de esta minería fue el momento del descubrimiento del caliche en cantidad y calidad (ley) suficientes para su explotación. Lo anterior era crítico para la decisión de seguir adelante o no en la explotación de una pampa, incluso en la implantación o no de una nueva oficina salitrera. Una noticia llegada de Valparaíso, principal centro mercantil del nitrato de soda, en 1867 nos ilustra al respecto:

"La nueva condición en las ventas de salitre en Valparaíso.

Por el vapor de la mala de 20 de febrero hemos recibido de Valparaíso la noticia de que la ley del salitre a vender en aquel mercado se ha fijado en $95 \%$, en lugar de $93 \%$ que fue anteriormente. El abono de ley que antes se pagaba, ha cesado, y si solo salitre de $95 \%$ se

\footnotetext{
${ }^{13}$ González, Sergio. 2004. “La lixiviación cultural del hombre y el desierto (1830-1930): la transformación del desierto en pampa y del enganchado en pampino", en Revista Polis № 9, vol. 3, Santiago, pp. 319-334.

14 González, Juan Antonio. 2018.“La Compañía de Salitres de Antofagasta, Chile. El desafío de su modernización empresarial e innovación estratégica”, en Estudios Atacameños № 60, San Pedro de Atacama, pp.133-159.
} 
cotiza, se castiga moderadamente el de menos ley hasta 93\%, cando el castigo es más fuerte por lo que baje de ello hasta $90 \%$ que es el límite más bajo a que será admitido [...].

[...] El salitre de $95 \% \%$ requiere mucho más esmero y cuidado en la elaboración que el 93\% esto es bien conocido y una parada de fondos grandes da por producto diario cosa de 27 quintales mientras que de salitre común puede dar 31 hasta 32 quintales [...]"15.

Los mineros de Tarapacá, que fueron los primeros en localizar y comercializar el salitre, arriesgaron sus capitales y sus vidas en esa empresa de extraer salitre de las pampas de esta provincia. Conocían las propiedades del salitre para la fabricación de pólvora negra y como fertilizante, pero desconocían sus posibilidades comerciales, por ello, Valparaíso se transformó en la plataforma comercial y pivotante con el mercado internacional.

A los mantos de caliche que se ubicaban en las pampas, generalmente ubicados al piedemonte oriental de la cordillera de la costa, se les denominaba "criaderos de salitre". Y la principal tarea de los cateadores era localizarlos e iniciar el pedimento y, como la normativa minera limitaba el número de estacas por persona, se organizaba una sociedad integrada generalmente por familiares, incluyendo padres, esposa e hijos, parientes y amigos. Posteriormente, emergerán sociedades organizadas sobre la base de intereses comerciales, y los "habilitadores" o "aviadores" que financiaban los procesos de implantación de las oficinas salitreras comenzarían a transformarse en compañías salitreras. Algunos tendrán un papel dominante en la fase de la industrialización de esta minería, como las Casas Gibbs, Gildemeister, Hainsworth, Granja, entre otras ${ }^{16}$. Fueron, por lo mismo, muy pocos los "cateadores" del periodo temprano del salitre que perduraron y devinieron en industriales, porque se requería de una capacidad empresarial que estuvo por sobre la mayoría de estos aventureros y osados mineros de Tarapacá.

Por lo anterior, es que se destaca la figura del minero tarapaqueño Asencio Almonte de La Fuente, quien representa además la tradición minera argentífera que se transfirió a la minería del nitrato de soda. Almonte fue un actor clave en ese periodo del ciclo del salitre al ser un cateador/descubridor y empresario exitoso.

Analizaremos ese proceso de descubrimiento y explotación de una pampa salitrera: Lagunas. Describiendo el largo desenvolvimiento de esta pampa, desde que era solo un salar en el territorio más austral y remoto de la provincia de Tarapacá hasta su transformación en un importante cantón salitrero.

\footnotetext{
${ }^{15}$ El Mercurio de Tarapacá, marzo 2 de 1867, p. 1

16 González, Sergio. 2020. "Agua Santa, espacio pivotante de la industria del nitrato de soda en Tarapacá. Los periodos "peruano" y "chileno" de la oficina más emblemática del ciclo de expansión del salitre", Revista Interciencia $\mathrm{N}^{\circ} 9$, vol. 45, Santiago, pp.434-440.
} 


\section{El descubrimiento de Lagunas}

Hubo un minero de linaje tarapaqueño -en toda su ascendencia- que fue el descubridor de los primeros mantos calichales en el territorio que sería después el cantón Lagunas. No solamente fue un exitoso cateador, sino quien nombró a esa hoyada como "Lagunas".

Tenemos su testimonio sobre su actuar como cateador y descubridor de Lagunas en los carteles que la normativa le exigía para acceder los estacamentos. Como estos "carteles" están escritos en un español propio de mediados del siglo XIX, se ha corregido al español actual para una mejor comprensión lectora:

"Asencio Almonte Vecino de Pica, ante US respetuosamente y como más haya lugar en dro. (derecho) me presento y digo que en el lugar nombrado la Laguna, distante (rayones), de mi anterior descubrimiento de Salitres, y en el camino que se dirige a la Caleta Guanillo; tengo descubierto terreno de salitre y habiendo (tres palabras ilegibles), y como estos descubrimientos que tengo hechos, en esos inmensos desiertos son hechos a costa de mis inmensos gastos, y sacrificios. Ocurro a la rectitud de su juzgado, para que con arreglo a la Ley Modificadora (ilegible) que los terrenos criaderos de salitre se consideren como terrenos eriazos, y no ya sujetos a la Ordenanza de Minería, me adjudiqué como descubridor, una Legua de terrenos para mí y mi Compañía compuesta con mis hijos Benedicto, María, Ignacio, Antonia y (ilegible) no protestando elaborarlo en el término de Ley por lo que suplico a US nombrar la persona que debe ponerme en posición, para planta la Oficina de elaboración del (ilegible). Por tanto. A US, pido y suplico, que habiéndome (ilegible) provea y mande lo que estime de justicia. Juro en Dios no proceder de malicia y para ello etc. (Erratas). Tarapacá agosto 2, 1850. Asencio Almonte." ${ }^{17}$

De este modo, Asencio Almonte, inició legalmente sus pedimentos en un lugar que él denominó Lagunas y que, por su amplia extensión y desconocimiento general de esas pampas, es que no solicita "estacas" como era habitual, sino "una legua para mí y mi compañía". Precisamente, por esa forma irregular de pedimento es que el gobernador de Pica, le comisiona a Juan Lema Morales para que le adjudique a Asencio solo cuarenta estacas. Un área que en la época se podría calificar de gran tamaño, puesto que los pedimentos solían ser de unas pocas estacas de criadero de salitres para implantar una o más Paradas salitreras.

"En 7 de noviembre de 1850, se le adjudican otras 12 estacas a Asencio Almonte.

D. Asencio Almonte a descubierto en la serranía de los Puquios, terrenos criaderos de Salitres, y siendo una de las atribuciones de esta autoridad, proteger la Industria. Hágase la adjudicación de doce estacas $q$. le corresponden a él y la $\mathrm{C}^{\circ}$ con sus hijos, nombrase para la

\footnotetext{
17 Fuente: Archivo Regional de Tarapacá, DIBAM. Archivo Sernageomin [ARTSNGM], Libro titulado: Nómina de oficinas Salitreras D.F. (delegación fiscal), Numerado 16. Año 1878. Fojas s/f.
} 
mensura y posesión a D. Lorenzo Olcay quien la efectuara con arreglo a Ley. Actuado con de Escribano. Juan Chocano. Lecaros. (ilegible)." ${ }^{\prime 18}$

La Serranía llamada de los Puquios era una de las indicaciones de Lagunas, visto ese lugar desde Pica, que era el Distrito al que pertenecía todo ese territorio incluyendo Quillagua y el río Loa hasta su desembocadura. La tabla 1 nos muestra la población del Distrito de Pica en el censo de 1862.

Tabla 1. Censo Poblacional de 1862

\begin{tabular}{|l|c|}
\hline Distrito de Pica & Población \\
\hline Pica & 1.016 \\
\hline Matilla & 491 \\
\hline Valle & 219 \\
\hline Huatacondo & 368 \\
\hline Quillagua & 77 \\
\hline Tirana & 215 \\
\hline Canchones & 60 \\
\hline Nueva Noria & 665 \\
\hline Cocina & 361 \\
\hline Yungay & 489 \\
\hline Total & 3.901 \\
\hline
\end{tabular}

Fuente: El Mercurio de Tarapacá, marzo 27 de 1868, p. 3.

El distrito de Pica era el que contaba con la segunda mayor población provincial, solo superado por el distrito de Camiña. Vemos que registra población en cantones salitreros como Nueva Noria, Cocina y Yungay, pero no se menciona a Lagunas. También se observa un asentamiento humano muy reducido en Quillagua.

Los mineros originarios de Pica-Matilla, como la familia Almonte, solían catear dentro del distrito, porque las autoridades eran favorables para sus aspiraciones y solicitudes.

El cartel siguiente es el más importante -para nuestro propósito-, pues hace referencia al origen del nombre de Lagunas y su condición de "descubridor".

"Asencio Almonte como a mi derecho. Conviene ante US. me presento y digo: Fui sociedad con D. José Manuel Loaiza y mi hermano Matías Almonte tengo descubierto terrenos salitre en la serranía de los Puquios al norte de este campo, en el lugar que por nombre se pone la Laguna, por haber encontrado al fondo de la hoyada descubierta, agua al Sol, que forma Lagunas; y como en los citados terrenos que he descubierto, trato de emprender el laboreo

${ }^{18}$ ARTSNGM, Libro titulado: Nómina de oficinas Salitreras D.F. (delegación fiscal), Numerado 16. Año 1878. Fojas s/f. 
de salitres; me presento en forma, como uno de los descubridores; para que se me adjudiquen las estacas que me corresponden a mí, y mis hijos que represento que son, Benedicto, María, Antonia, e Ignacio; siendo el terreno que solicito a la inmediación de la citada laguna y al rumbo que yo juzgue conveniente, por tanto. A US Pido y suplico así lo provea y mande según tengo pedido por ser justicia. Juro en derecho. Lo necesario y para ello etc. Pica noviembre 8 de 1850. Asencio Almonte" ${ }^{19}$.

Para entonces Asencio Almonte contaba con cuarenta años y una larga experiencia minera. Este cartel es resultado, posiblemente, de múltiples intentos en la búsqueda de salitre, que pudieron tomarle años.

Óscar Bermúdez como buen conocedor del desierto de $\operatorname{Tarapacá}^{20}$, sabía que los mirajes o espejismos eran habituales en las pampas, especialmente las del sector sur de Tarapacá debido a los salares, por ello supone que ese es el origen de la palabra "Lagunas": "El nombre Lagunas se dio a ese espacio salitrero por los mirajes que diariamente se observan simulando lagos o visiones marinas entre el Salar Sur Viejo y la Pampa Tente en el Aire"21.

Sin embargo, el propio Asencio Almonte nos aclara como vimos en el cartel citado más arriba: "en el lugar que por nombre se pone la Laguna, por haber encontrado al fondo de la hoyada descubierta, agua al Sol, que forma Lagunas...". No dice que por el reflejo del sol se observa el agua en forma de lagunas. Las aguadas no eran extrañas en el desierto del Tamarugal. Además, "Lagunas" está muy próxima al delta de la quebrada de "Manin" y también del salar de "Llamara". De hecho, el Pozo de Lagunas está al borde de este salar (ver mapa 1).

Asencio identifica en su cartel como socio a José Manuel Loaiza. Este personaje era un destacado vecino de Pica y Matilla. Su nombre era José Manuel Loayza y Soto, nacido en Matilla el 14 de marzo de $1788^{22}$, estaba casado con Gabriela Lecaros Baltierra, perteneciente también a una conocida familia salitrera. Posiblemente, José Manuel, actuó de habilitador o financista de Asencio. Cabe adelantar que, por el lado materno, Asencio procedía de una importante rama Loayza. Además, Carmen, la esposa de Asencio, se apellidaba también Loayza.

\footnotetext{
${ }^{19}$ ARTSNGM, Libro titulado: Nómina de oficinas Salitreras D.F. (delegación fiscal), Numerado 16. Año 1878. Fojas s/f. 20 Óscar Bermúdez nació en Tarapacá y vivió en la oficina salitrera Josefina.

21 Bermúdez, Óscar. 1963. Historia del salitre. Desde sus orígenes hasta la guerra del Pacífico. Ediciones de la Universidad de Chile, Santiago, p. 262.

22 Pertenecía a la familia Loayza y Soto de los marqueses de la Matilla de Umbría en España. Ver: Torres, Alflorino 2017. Familias fundadoras de Pica y Matilla. Incluye Cumiñalla, La Huayca, Huatacondo, Quillagua y el puerto de EI Loa, 1590-2015, Ediciones Universidad de Tarapacá, Arica, pp.596 - 597.
} 
Mapa 1. Cantones y ferrocarril salitreros

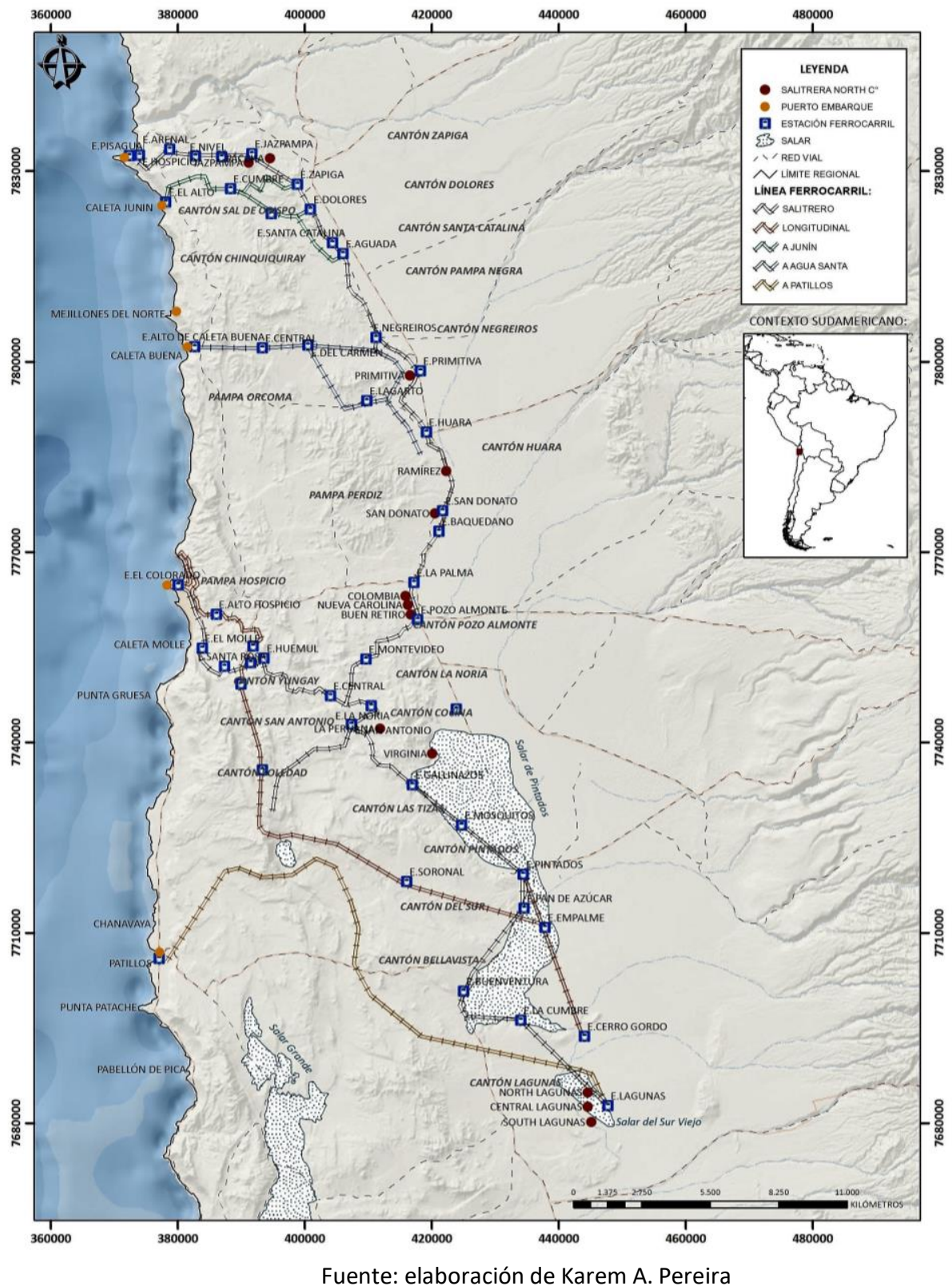

El otro socio que menciona era su hermano mayor, Matías, de quien nos referiremos más adelante; si bien podríamos suponer que le acompañó en sus expediciones a las orillas del salar 
en Lagunas, pero no tenemos certeza de ello. Si la tenemos respecto de su sobrino Manuel Almonte y Vigueras ${ }^{23}$, hijo de su hermano, que le seguía en edad, también llamado Manuel.

Consideramos relevante destacar que los terrenos que le correspondió catear a Asencio y sus familiares y amigos, fue uno de los más complejos y difíciles, porque estaba en los bordes de los salares, también eran lugares de eventuales avenidas de agua, etc. En el estudio de los ingenieros alemanes Semper y Michels, se señala que en ese tipo de terrenos se debe cambiar la técnica de cateo:

"Para catear los terrenos atravesados por ríos secos o los que tiene rezumaderos o masas acumuladas de aluvión, o salares u otras demostraciones que permiten predecir de antemano una formación irregular, hay que proceder de otra manera" ${ }^{24}$

Volviendo a los cateos de Asencio. Es muy interesante anotar la forma como se asignaban en esa época los estacamentos salitrales. Veamos el caso de las 12 estacas mencionadas más arriba, las que le fueron encomendadas a Lorenzo Olcay para entregarlas oficialmente a Almonte:

"Abril trece de mil ochocientos cincuenta y uno. En cumplimiento de la comisión a mí conferida por el Señor Subprefecto pase al lugar que en ella se indica que certifico. Lorenzo Olcay. En el lugar nombrado La Laguna en el distrito de Pica, Prov ${ }^{\circ}$ de Tarapacá, en el Departamento de Tacna, a los trece días del mes de abril de mil ocho cientos cincuenta y un años. Yo, el comisionado Lorenzo Olcay por el Señor Sub-Prefecto de la Prov ${ }^{\circ}$, para poner en posición a D. Asencio Almonte de doce estacas de terreno criadero de Salitre como descubridor; pasé al lugar indicado, y después de mensurado el terreno puse en posesión a nombre del Estado, al referido D. Asencio Almonte luri Domine Bel cuasi, siendo la posición determinada y señalada por amojonamiento en los que se encuentran los Certificados que señalan los linderos y rumbos de cada estaca que se ha medido por doscientas varas cuadradas como esta mandado y determinado en las mensuras que se practican en esta clase de terrenos: Y en señal de verdadera posición, lo paseé por toda ella dio voces (ilegible) terreno con otras más demostraciones que acreditaba su dominio y señorío que tomo de las mencionadas doce estacas, y lo firmó conmigo de que certifico entre renglones. Laguna. Lorenzo Olcay. Asencio Almonte. Tgo. (ilegible) Loayza. Tgo. Manuel Morales. Tgo. Juan Soto". 25

\footnotetext{
${ }^{23}$ Fue uno de los personajes más destacados de Tarapacá en la década de 1860. Amigo muy cercano de Ramón Castilla Marquesado y fue quien encabezó la revolución tarapaqueña de enero de 1868, al término de la cual fue designado temporalmente Prefecto de Tarapacá. Fue salitrero (dueño de la oficina La Palma) y agricultor. ${ }^{24}$ Semper, Erwin. y Michels, E. 1908. La industria del salitre en Chile, Imprenta Barcelona, Santiago, p. 45.

${ }^{25}$ ARTSNGM, Libro titulado: Nómina de oficinas Salitreras D.F. (delegación fiscal), Numerado 16. Año 1878. Fojas s/f
} 
El comisionado Lorenzo Olcay tenía perfecto dominio de su función: realizó la mensura, caminó el estacamento junto a Asencio como muestra de posesión y le pidió las manifestaciones necesarias para que consolidara su propiedad, en este caso fueron voces (gritos), también se solía tirar piedras o revolcarse en la tierra.

Nos interesa mucho el calificativo de "descubridor" de Asencio Almonte, al ser el primero y no tener referencias mineras anteriores debió "nombrar" los terrenos que cateaba. De ese modo también comenzó a surgir un "habla salitrera", pues no solo los cateadores debieron "nombrar" lugares sino también las herramientas, las materialidades y la técnica minera que surgía de la minería del nitrato. Basta para sorprendernos los diferentes nombres que le asignaron al caliche ${ }^{26}$.

Aceptando la sentencia de Gregory Bateson que "el mapa no es el territorio y el nombre no es la cosa nombrada" 27 , con el paso del tiempo y cuando dicho nombre se socializaba y pasaba de generación en generación, en un determinado momento ya no se podía separar el nombre de la cosa nombrada. En la actualidad no podemos imaginar el territorio ubicado al extremo sur de la provincia de Tarapacá, en la faja central del desierto, sin que el nombre de "Lagunas" se gatille en nuestro cerebro.

Existe una referencia a la familia Almonte en el clásico libro del historiador Óscar Bermúdez Miral, donde señala que se había interesado en salitre ya en 1850-51, pero le adjudica esta iniciativa a Manuel Almonte y Vigueras, a saber:

“[...]cuando don Manuel Almonte Vigueras adquirió 40 estacas en los bordes de Bellavista, el sector que entonces trabajaba don Juan Williamson. A la actividad de los Almonte, originarios de Pica y que compartían la vida del oasis con la exploración de ese lado del desierto, abriendo pozos en los bordes de los salares y descubriendo y adjudicando yacimientos de caliche, se debió el nombre del pueblo de Pozo Almonte. Uno de ellos perforó el Ilamado después Pozo Seco de Almonte, más al Sur del Salar de Sur Viejo [...]" ${ }^{28}$

En general la información entregada por Bermúdez es correcta, pero hay detalles que no son totalmente exactos. En primer lugar, Bermúdez nos indica que los Almonte se enfocaron en el territorio de Tarapacá al sur de Pica, lo que es cierto para la mayoría de los cateos y pedimentos requeridos por los integrantes esta familia; pero, el abuelo de Manuel Almonte y Vigueras, y padre de Asencio, cateó mucho antes en un sector conocido como "Saca Si Puedes", que después cedería su nombre por el de Camiña. "Saca Si Puedes" estaba ubicado en el cantón Pampa Blanca, que posteriormente se conocería con el nombre de Cantón Santa Catalina,

\footnotetext{
${ }^{26}$ Ver "Glosario de voces de la pampa" en: González, Sergio. 2002. Hombres y mujeres de la pampa. Tarapacá en el ciclo de expansión del salitre, Santiago, Editorial LOM.

${ }^{27}$ Bateson, Gregory 2002. Espíritu y naturaleza, Buenos Aires, Amorrortu Editores, p. 40.

${ }^{28}$ Bermúdez, Óscar 1963. Op. Cit., p. 262.
} 
siendo el principal puerto de embarque Pisagua. Es decir, muy lejos de Bellavista y de Lagunas. Además, muy al norte de Pica (ver Mapa 2).

Mapa 2. Principales valles de la Provincia de Tarapacá

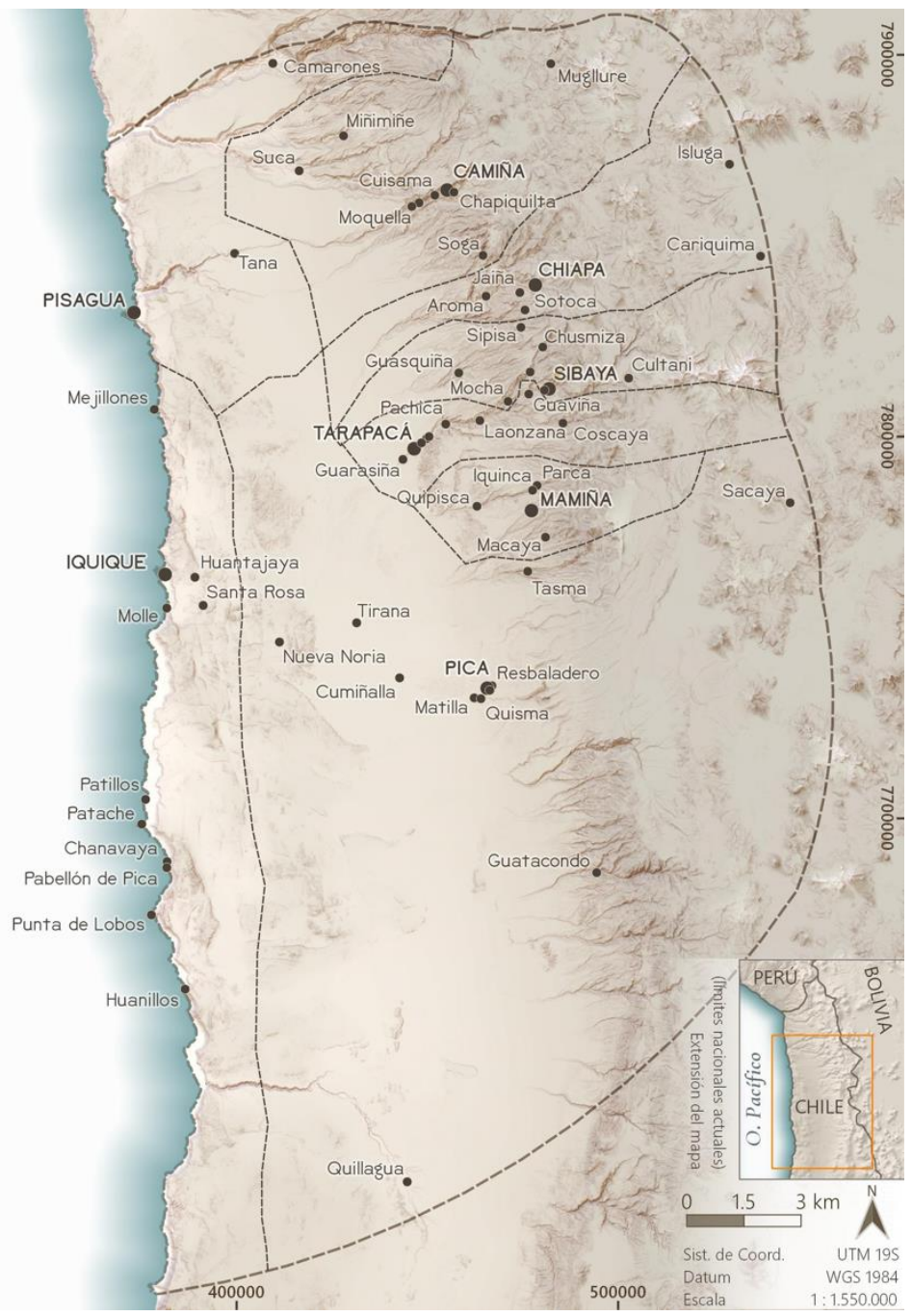

Fuente: elaboración de Maximiliano Barrientos

Bermúdez afirma que "uno de ellos perforó el llamado después Pozo Seco de Almonte, más al Sur del Salar de Sur Viejo", aquí se refiere, sin nombrarlo, a Asencio Almonte.

Respecto del pueblo de Pozo Almonte, que está al norponiente de Pica, tenemos una extensa carta publicada en El Comercio de Iquique, firmada: Pica, mayo 25 de 1875, donde varios vecinos de Pica solicitan que su Distrito se convierta en Provincia, señalando a sus más renombrados precursores de la minería del salitre: 
"De pública notoriedad es en la República, que cuando se descubrió el negocio salitres, Iquique solo existía como una insignificante caleta: los hijos de este distrito, se lanzaron al laboreo de esa nueva industria, con sus capitales unos, con sus créditos y fuerzas personales otros, sin que los arredrara los inmensos obstáculos que toda empresa nueva trae consigo cuando se trata de implantarla en desiertos como entonces lo fueron la Nueva Noria, Salar, Cocina, Yungay, Paposo, San Antonio y oficinas llamas "de afuera", donde trabajaron los Bustos, Almonte, Arias, Vera, Loayza, Riveros, Morales, Verdugo, Núñez y tantos otros hijos de nuestro Distrito. Después de inmensos sacrificios y penalidades sin cuenta, se logró sistemar este negocio en donde día por día sostuvieron una lucha titánica por mantenerse y hacerlo digno de que diera ventajosos resultados ${ }^{\prime 29}$.

Pozo Almonte corresponde a lo que se conoció tempranamente como oficinas "de afuera" $y$, como vemos, fue un territorio próximo a los salitreros provenientes de Pica, entre ellos, los Almonte, pero no fueron los únicos. Respecto de los pozos de agua en ese sector que dio por origen a la oficina Pozo Almonte, tenemos antecedentes de un denominado pozo "Sacramento", en un lugar que, antes de 1830, se le denominó "Terrible". En 1829, Joaquín Elizalde, denunció ante la diputación de minería "10 estacas de salitre en compañía de doña Escolástica Verdugo, doña Juana Verdugo, mi madre doña Teresa Ceballos y mi esposa doña Tomasa Arco." ${ }^{\prime 30}$ Esta familia es anterior a todos esos apellidos señalados por los vecinos de Pica en 1875 , y no era originaria del oasis. Otro cateador de esas pampas fue Nazario Baltierra y Ceballos, que sí tenía vínculos con Pica-Matilla.

De todos modos, es muy relevante comprender que el cateo se fue "moviendo" hacia el sur del salar de Pintados, llegando primero al salar Bellavista, para continuar con el salar de Sur Viejo y el salar de Yamara o Llamara. Óscar Bermúdez le entrega el crédito de esa iniciativa a los británicos, en particular a John (o Juan) Williamson, quien llegó a Tarapacá en 1836. Asociado con su tío, cateó en la orilla occidental del salar de Bellavista. Bermúdez afirma que el quehacer de los británicos despertó el interés de los peruanos:

“[...] Y ya en 1851 la Subprefectura de Tarapacá hacía las siguientes adjudicaciones de terrenos en Bellavista: 40 estacas a don Manuel Almonte y Vigueras, 20 a don Venancio Guacucano, otras tantas a los señores José Quiroga, Gil Ulloa y Juan Morales y menos de 20

\footnotetext{
${ }^{29}$ El Comercio, Iquique, junio 20 de 1875, p. 4.

30 ARTSNGM, Libro titulado: Nueva Carolina y Pozo Almonte. Cantón San Antonio. Numerado 6. Contrato entre Fernando López y el Supremo Gobierno del Perú. Año: febrero 15 de 1879. Fojas s/f.
} 
estacas por persona a doña Lucía Pérez Obligado ${ }^{31}$, Manuel Silvestre Olcay, Blas Morales y Miguel Quisucala"32.

Más adelante retomaremos la importancia de Juan Williamson, un salitrero que además nos dejó un análisis sombrío de la economía generada por la industria del salitre de la primera mitad del siglo XIX. ${ }^{33}$

Bermúdez en la única referencia que tiene de Asencio Almonte, nos dice lo siguiente:

“[...] era dueño en 1870 de más de 400 estacas en Las Lagunas, situadas las mejores en el punto denominado Lagunillas $[\ldots . .]^{\prime 3}{ }^{34}$

Efectivamente, Asencio Almonte poseía hacia 1870 exactamente 408 de estacas, pero Bermúdez omite cuándo y cómo las obtuvo. Ese vacío lo abordamos aquí. En el siguiente Cartel, vemos más detalles de su cateo en Lagunas y la participación de su sobrino Manuel Almonte y Vigueras.

"Asencio Almonte, ante V. como mejor haya lugar comparezco y digo: que habiendo cateado en compañía de mi sobrino D. Manuel Almonte y Vigueras, al sud los intereses de salitre (ilegible) descubiertos; hemos encontrado unos salares al sur del camino que baja de los Puquios a la caleta de Guanillos, en las que a mi parecer hay terrenos salitreros; y deseando establecer allí, una Oficina de Salitres, ocurrimos a su integridad para que se digne adjudicarnos sesenta estacas para trabajarlas en compañía de mis hijos, Benedicto, María, Antonia e Ignacio; y mi hermano Matías, su esposa Manuela, sus hijos, Miguel, Francisco y Isabel; y mi sobrino Manuel, su esposa María, sus hijos, Benjamín Miguel Almonte sus domésticos o hijos Mariano y Antonio; mi sobrino Olegario Almonte, y D. Gilberto Olcay, D. Santos Olcay, Asencia Olcay; y Doña Justa Tinajas y sus hijos, D. Santiago Zavala, Da. Manuela, D. Juan Bautista, D. Nicolas, Carmen, Lorenzo, Victoria Zavala; y sus tíos, D. Ildefonso, y D. (ilegible) Zavala; ofreciendo por mi parte y la de mis representados, por trabajo, tan luego como se nos ponga en posesión, por tanto, a US pido y suplico que habiéndome por presentado, se digne (ilegible) la adjudicación que solicito, juro lo necesario y para ello etc. Tarapacá 30 de abril 1852. Asencio Almonte." ${ }^{35}$

\footnotetext{
${ }^{31}$ En otro trabajo hemos pesquisado la vida de don Pedro Pérez Obligado, minero de Huantajaya y descubridor de la oficina Ramírez, padre de Lucía Pérez Obligado.

32 Bermúdez, Óscar. 1963. Op. Cit., p. 135.

33 Williamson, Juan. 1860. Observaciones sobre la industria de la provincia de Tarapacá. Tipografía de Mariano Gómez y $\mathrm{C}^{\circ}$, Callao.

${ }^{34}$ Bermúdez, Óscar 1963. Op. Cit., p. 262.

${ }^{35}$ ARTSNGM, Ob. Cit. Año 1878. Fojas s/f.
} 
Queda plenamente establecido que se trataba de una sociedad basada en la familia, por ejemplo, los Olcay estaban emparentado a través de la esposa de Manuel Almonte y Vigueras, la señora María Olcay Morales. Los Zavala señalados eran naturales de Pica-Matilla y descienden de Santiago Zavala y Echeverría y de Justa Tinajas Nestares. Sus hijos Domingo, Juan Bautista, Lorenzo y Carmen, fueron reconocidos salitreros.

La persona comisionada para hacer entrega oficial de las sesenta estacas mencionadas fue José Almonte, a saber:

“Pica, Sept. 28 de 1852.- Por recibida: Pásese (ilegible) al lugar indicado acompañado de los Tgos. competentes para practicar la diligencia de posesión ordenada por el Sr. Subprefecto de la Prov $^{\circ}$ con fecha (ilegible) del que corre; y hago saber al interesado. José Almonte.

En el lugar nombrado serranía de la Soledad del Distrito de Pica, a los veinte días del mes de octubre de mil ochocientos cincuenta y dos: Yo, el comisionado José Almonte acompañado con los Tgos. que suscriben y en cumplimiento de la comisión que antecede constituido en el lugar ya citado, he mensurado las sesenta estacas a doscientas varas y amojonado sus respectivos linderos poniendo los certificados: En cuya virtud y en cumplimiento de mi comisión tome de la mano a Don Asencio Almonte, y lo pasee en posesión real y corporal Jure Domine bel Cuasi quien [corte de pág.] en nombre del Estado sin contradicción alguna y se paseó por toda ella, dio voces, deshizo terrenos, otras más demostraciones que acreditaban su dominio y señorio q. tomo de los denominados terrenos, con lo que se concluyó este acto de posesión y lo firmó conmigo y Tgos. de que certifico. José de Almonte. Asencio Almonte. Tgo. Juan Lema. Tgo. Bartolo Loayza. Se dio testimonio en 30 de marzo 1870. doy fe. Ramírez" ${ }^{\prime 36}$.

Estos procedimientos eran los habituales para la adjudicación de los estacamentos, tanto la forma como se realizó la petición, la unidad de medida, la inclusión de familiares y amigos, así como el ritual de entrega.

Antes de continuar con la estrategia de Asencio Almonte para adquirir su gran estacamento, que permitió organizar una de las sociedades salitreras más ambiciosas y controvertidas del período peruano, la Compañía La Esperanza, debemos preguntarnos por el sujeto. ¿Quién era realmente Asencio Almonte de La Fuente?

\section{La imagen del cateador: Hermenegildo Coca y Asencio Almonte}

En el imaginario de quienes estudiamos la minería del salitre siempre se asocia la figura del cateador con Hermenegildo Coca, y es una figura construida en contrapunto con la del

\footnotetext{
${ }^{36}$ ARTSNGM, Ob. Cit. Año 1878. Fojas s/f.
} 
empresario José Santos Ossa, quien se llevó los créditos del descubrimiento del salitre en Antofagasta y la creación de la Compañía salitrera la "Exploradora del Desierto de Atacama", implantando la primera máquina de lixiviación de nitrato de soda. Así lo confirma el historiador antofagastino José Antonio González: "Los antecedentes de la Compañía de Salitres y Ferrocarril de Antofagasta hunden sus raíces con el descubrimiento de salitre por José Santos Ossa en 1866 y las amplias concesiones que otorgó el gobierno de Bolivia para la explotación del recurso a la Sociedad Exploradora del desierto de Atacama". ${ }^{37}$

Por su parte, Isaac Arce, reconoce la búsqueda anterior de los hermanos Latrille y, además, menciona al cateador Hermenegildo Coca:

“Parece que la gente del señor Ossa siguió el mismo derrotero de los Latrille, pues llegó también, como ellos, hasta el Cerro de Plomo, con el objeto de reconocerlo y extraer muestras, a la vez que cateaba el Salar, cerca de la actual estación de Portezuelo, kilómetro 29 del F.C. a Bolivia. Esto se explica fácilmente pues el baqueano que los guiaba fue el mismo que guio la expedición de los hermanos Latrille. Este era un indio boliviano Ilamado Hermenegildo Coca". ${ }^{38}$

La descripción de Roberto Hernández de esa famosa expedición de José Santos Ossa de 1866 es aún más gráfica:

"Componían la expedición: el indio Hermenegildo Coca, que era el práctico y la bruja, con sandalias de piel de guanaco en los pies y un rebozo de bayeta encarnada en el cuello; Juan Villarroel, un antiguo marinero chileno que había navegado hasta California y que por allá también había estado buscando oro, aunque con mala suerte; Juan Zuleta cuidador de las cabalgaduras y sus cargas; José Poblete, otro arriero; Pedro Brechart y Carlos Nepont, antiguos marineros, pero buenos también como cateadores; un chango que arreaba los burros que conducían el agua; dos peones más para la carga y descarga de los víveres y otro peón ranchero, que lo apodaban el rubio, un roto hecho y derecho, a quien por el momento se le había confiado la cocina. Finalmente, montados en buenos caballos, iban a la retaguardia don José Santos Ossa y su hijo mayor Alfredo, a la sazón de solo dieciséis años de edad". ${ }^{39}$

La imagen de Hermenegildo Coca que nos entrega Roberto Hernández se asemeja más a la de un llamero o caravanero andino que a la de un cateador de salitres, al menos como los que

\footnotetext{
37 González, José Antonio 2017. “La Compañía de Salitres de Antofagasta, Chile. El desafío de su modernización empresarial e innovación estratégica", Estudios Atacameños Nº 60, San Pedro de Atacama, p. 134.

38 Arce, Isaac 2004. Narraciones históricas de Antofagasta, Antofagasta, Corporación Pro-Antofagasta (edición original 1930), p. 62.

39 Hernández, Roberto 1930. Op. Cit., p.60.
} 
hemos pesquisado en Tarapacá. Esos cateadores le llevaban medio siglo de ventaja en la minería salitrera a cualquier baqueano de otras comarcas del desierto de Atacama. Para ser un cateador de caliches se requería no solo conocimiento del desierto y de algunas técnicas mineras, sino tener capitales y/o formar parte de una sociedad que le ofreciera redes de apoyo. También era imprescindible pertenecer al gremio de los salitreros. A muchos de ellos se les asignó el nombre de "descubridor", por ser quienes encontraron por vez primera una pampa rica en criaderos de salitre, lo que les valió mucho prestigio entre los mineros contemporáneos.

En Antofagasta, Hermenegildo Coca no fue reconocido como descubridor, porque la campaña que realizó la hizo en compañía de su habilitador: José Santos Ossa.

En la visión que se tenía al sur de Taltal, sobre la base de la experiencia conocida en Copiapó, los cateadores podían ser baqueanos, pirquineros, sujetos conocedores del desierto, aventureros sin capital ni cultura empresarial. Hermenegildo Coca era en ese imaginario chileno, por cierto, "un indio boliviano", bastaba con su nombre y su oficio. Y esa imagen ha quedado grabada en piedra. El poeta Andrés Sabella, en su intento de rescatar y valorar la figura de Hermenegildo termina reafirmando esa imagen:

\author{
La estrella de los cateos \\ entra en las manos de Coca. \\ Dice José Santos Ossa: \\ -iDeme el diablo un derrotero! \\ Pálido el indio hasta el hueso \\ donde Dios, sombrío, llora, \\ persigna su frente angosta: \\ -iNo somos hijos de perro...! \\ Y con negrísimo ceño: \\ -iA usted el Santos le sobra..! \\ Ríe el patrón y en sus botas \\ fragua el polvo un vago enredo. \\ Hermenegildo, sin gestos, seguro en su diestra toma \\ oscura tierra y la sopla \\ sobre el rostro del misterio $[\ldots]^{40}$.
}

No cabe aquí profundizar respecto de la biografía de Hermenegildo Coca, pero, al menos, ponemos en duda esa imagen del cateador de salitres en Antofagasta que surgió de la pluma de sus cronistas e historiadores.

40 Sabella, Andrés 1978. “Caravana de Cobija” en Hombre de Cuatro Rumbos, Santiago, Editorial Nascimento, p. 53. 
No pocos fueron los salitreros que descubrieron salitre en Tarapacá y que tuvieron apellidos "indígenas bolivianos" y que, sin embargo, formaron parte de la elite minera que levantó las primeras paradas salitreras: Quisucala, Vilca, Cayo, Calacoto, Choque, etc. Incluso el reconocido salitrero Atanacio Tinaxas que Óscar Bermúdez destaca en su clásico libro, su segundo apellido era Mamani. Su madre era boliviana. Los Tinaxas o Tinajas estaban emparentados con los Nestares, Bokenham, Almonte, etc. El apellido Coca es posible pesquisarlo en Tarapacá en el siglo XIX, pues existió una oficina de Parada llamada San Antonio Nuevo, cuya propietaria se llamaba Gregoria Coca.

Los primeros cateadores de salitre se forjaron en Tarapacá y algunos de ellos se trasladaron a las "salitreras de Bolivia". En 1869, un año que se podría definir de "tardío" todavía existía los temores de la competencia que pudiera surgir al sur del río Loa:

"Se aproxima para la industria salitrera de la provincia, una de las épocas de crisis a que no se ha querido dar crédito, por más que los hechos que la indicaran hayan sido manifiestos. Nos referimos a la sociedad organizada en Chile en que figuran la casa de Gibbs y $\mathrm{C}^{\circ}$, el banquero tan conocido don Agustín Edwards y algunos otros señores que tienen conocimientos prácticos del negocio, para la explotación de las salitreras de Mejillones de Bolivia.

No se tienen datos exactos de las riquezas de aquellas salitreras, de la extensión de los terrenos ni de las demás condiciones que faciliten el trabajo: a este respecto, o se ha procurado ocultar la verdad, o se ha esperado que el mal se aproxime sin oponer ninguna medida que ponga en salvo la industria local [... $]^{\prime 41}$.

Los inversionistas que iniciaron la minería del salitre en Antofagasta, como Agustín Edwards, José Santos Ossa, Milbourne Clark, Manuel Antonio de Lama, entre otros, habían trabajado en Tarapacá. Y para saber los "datos exactos de las riquezas de aquellas salitreras" debieron contratar a cateadores tarapaqueños.

Hemos pesquisado que el eje en torno al río Loa permitió a los cateadores de salitre de Tarapacá movilizarse hacia Chacance y el Toco cruzando el río Loa a la altura de Quillagua. La cultura de estos cateadores tarapaqueños no era la misma de aquella proveniente de la minería de altura (Bolivia) o de la de Copiapó. No sabemos si Hermenegildo Coca provenía de Tarapacá, pero afirmar que era boliviano en 1866 en un territorio que entonces pertenecía a ese país, no agrega mucha información.

No es fácil conocer cómo pensaba un cateador de esa época, porque no es común en los documentos mineros observar el registro de actitudes y percepciones. Sin embargo, contamos con un interesante testimonio de un salitrero que, producto de una omisión en la venta de su

${ }^{41}$ El Mercurio de Tarapacá, 6 de mayo 1869, p.1. 
estacamento, nos permitió recoger la calidad humana de una amistad surgida en el desierto. Nos referimos al estacamento San Rafael, ubicado a orillas del salar "Sur viejo", que después sería conocido como oficina salitrera La Granja.

Iquique, agosto 14 de 1872. Señor Rafael Falcón, presente.

Mi estimado compañero y amigo: Cuando se inició el cateo de los terrenos salitrales que poseo en el Sur Viejo, en compañía de María Choque y otros, convinimos en hacer los gastos Ud., y yo en la parte que nos tocase y que la Choque debía contribuir en proporción a las estacas que le corresponden, no ayudando en nada a las estacas las 25 estacas que debemos como gratificaciones. Así es que siendo el total de terreno 285 estacas, hay sujetas al pago proporcional de gastos 260, que pertenecen a las personas siguientes, a saber: María Choque 66 estacas, Rafael Falcón 97 estacas, Patricio Dawling 97 estacas, doscientas sesenta (260). Como los documentos que acreditan la posesión y dominio del terreno no aparece el nombre de Ud., que su trabajo personal y gasto proporcional que por su parte hace y sigue haciendo lo hacen acreedor a ser dueño del igual número de estacas que yo, y en este concepto puede Ud., hacer extender escritura que firmaré gustoso en cumplimiento del convenio verbal que hice. Es cuanto le dice su compañero y amigo. Patricio Dawling. ${ }^{42}$

¿Quién fue el cateador de este importante estacamento que diera origen a la oficina San Rafael y que posteriormente fuera la base de, nada menos, la oficina Granja, una de las más importantes del ciclo de expansión del salitre? ¿Patricio Dawling, Rafael Falcón o María Choque? No lo sabemos, solo podemos decir que, revisando la prensa de la época, sabemos que Rafael Falcón era un conocido sastre en Iquique, y en 1870 se asoció a Patricio Dawling para la venta de artículos para caballeros en ese puerto. De María Choque no hemos podido encontrar huellas, pero sabemos hubo mujeres cateadoras.

\section{Asencio Almonte: orígenes y redes familiares.}

Asencio Almonte de La Fuente fue un cateador como muchos que hubo en Tarapacá. Los que se transformaron en empresarios exitosos fueron una minoría. La mayoría terminó vendiendo o entregando sus estacamentos a otros empresarios o, por deudas, a los habilitadores. Asencio formó parte de esa minoría que le fue bien.

¿Quién era Asencio Almonte? Por el lado paterno, era hijo de Gregorio Almonte y Quiroga, el minero salitrero, al que hemos ubicado cateando en las pampas de "Saca Si Puedes". Más influyente fue su abuelo: José Garrocho de Almonte, minero en Huantajaya y en Tamentica.

\footnotetext{
42 Varios autores. 1900. Antecedentes, escritos y documentos relacionados con el juicio seguido por la familia Falcón y Mary y sus contrapartes, contra D. Matías Granja y D. Hijinio Astoreca ante los tribunales de lquique, sobre reivindicación de 91 estacas de la salitrera "La Granja" (antes San Rafael). Litografía e Imprenta Sudamericana, Valparaíso.
} 
Esta última referencia es relevante porque se trata de una minería próxima a Huatacondo. Veremos más adelante la importancia estratégica de este pueblo para el cateo de los criaderos de salitre de Lagunas. La esposa de José Gregorio Garrocho de Almonte, María Rosa López de Quiroga y Aller, descendía de un capitán de los reales ejércitos españoles, Cristóbal Ruperto de Quiroga y Osorio.

La herencia minera que recibió Asencio a través de los "Almonte" es innegable, sin embargo, no lo es menos por la línea de los "de La Fuente". Su madre era Melchora de La Fuente y Palacios, natural de Pica. Su padre fue Francisco de La Fuente, hijo natural nada menos que de José Basilio de La Fuente Haro y Loayza, el más importante minero de Huantajaya del siglo XVIII y una mujer tarapaqueña desconocida. José Basilio tuvo varios hijos antes de su matrimonio con María Jacinta de Loayza Calderón Portocarrero, descendiente directa del aristocrático Gaspar Jacinto de Loayza Valdez Ondegardo, llegado en el siglo XVI a Pica, donde funda esa importante familia.

Francisco de La Fuente, nacido en $1738^{43}$, se casó con Inés Palacios Irurtia de Aguilar, nacida en 1745, y tuvieron cuatro hijos: Matías (1766), Juan de Dios (1768), Melchora (1770) y Manuela (1771).

El tío de Asencio, Matías de la Fuente, tuvo el privilegio de ser reconocido como uno de los precursores de la industria del salitre, citado por todos los especialistas. Fue quien "emprendió el viaje al Alto Perú a principios de $1809^{\prime \prime 4}$ para entrevistarse con el naturalista Tadeo Haenke, para que este le entregara la fórmula para convertir el nitrato de soda en potásico. Matías implantó una "fábrica de salitres" en la caleta Tumbes, próxima a Talcahuano.

Melchora fue la madre de Asencio. Y su hermana Manuela la de Antonio Gutiérrez de La Fuente, el Gran Mariscal de Arequipa y prócer del Perú. Más adelante veremos la relación empresarial entre estos primos.

Melchora de la Fuente Palacios, nació en Pica, y se casó con Gregorio Almonte Quiroga, salitrero natural de la misma localidad. Melchora tuvo cuatro hijos: Asencio, Manuel, Raimundo y Matías.

Manuel Almonte de La Fuente, fue un importante agricultor y salitrero, y el padre de Manuel Almonte Vigueras, el más destacado de toda la familia Almonte.

Sobre Matías Almonte de La Fuente haremos una referencia más adelante, solo adelantaremos que nació en San Francisco de Chiu-Chiu, llamada Atacama "La Chica", el 4 de abril de $1809^{45}$.

\footnotetext{
${ }^{43}$ En el registro bautismal figura como hijo de padres no conocidos, aunque en su testamento José Basilio de la Fuente Haro y Loayza, lo reconoce como su hijo.

${ }^{44}$ Bermúdez, Óscar 1963. Op. Cit., p. 54.

45 Parroquia de San Francisco, Chiu-Chiu, bautizado en 1809.
} 
Asencio Almonte nació en 1810 y falleció el 12 de marzo de 1885. Tuvo una larga vida para los estándares de la época, que le permitió ser testigo del desarrollo de la industria salitrera desde el momento en que comenzaron a implantarse las primeras máquinas de vapor hasta cuando los principales dueños de esta industria ya no eran los tarapaqueños como él, sino europeos, mayoritariamente ingleses.

La familia fue una institución muy importante en la emergencia de la explotación del salitre en Tarapacá. Los pedimientos mineros de estacamentos salitreros, al igual como se realizaba con las estacas en las minas de plata, se hacían a nombre de los integrantes de la familia: padres, hijos, hermanos. A veces se incluía a amigos y socios. Esta fue la estrategia de Asencio Almonte para asegurar que su descubrimiento de criaderos de salitre en Lagunas creciera y quedara en manos conocidas. Veamos algunos ejemplos:

"Manuela Almonte, por mí y a nombre de mis hijos que represento, hasta US. me presento y digo: que en el lugar nombrado la Laguna, y en el que han descubierto criaderos de salitres D. Asencio Almonte y su compañía; se encuentra una rinconada al norte de ésta, con un Salar a su frente, y como en el citado terreno, hay criadero de salitres; nombro este sitio, como punto cierto y determina, para que, en él, se digne, la justificación de US. adjudicarme las Estacas que me corresponde, a mí, y mis hijos que represento, Fermina, Santiago Salvador José Manuel y Clementa; prometiendo elaborar dichos terrenos en el término que juzgue conveniente. Por tanto. A US pido y suplico, que, habiéndome por presentado, se digne proveer, lo que estime de justicia. Juro en Dios lo necesario, y para ello etc. Pica nov. 8, 1850. Otro si digo. Que por falta absoluta del papel sellado se sirva admitir mi recurso en papel común con cargo de reintegro. A ruego de mi madre Doña Manuela Almonte firmo yo por ella. Fermina Almonte" 46 .

Manuela y sus hijos son parientes de Asencio, pero no en línea directa. Manuela Almonte Almonte, era hija de Damián Almonte y de Fernanda Almonte, primos. La estrategia de Asencio queda en evidencia a los pocos meses, con la cesión que Manuela Almonte le hace de su estacamento:

"Conste por la presente cesión, que cedimos y pasamos a favor de D. Asencio Almonte el dro. (derecho) Que tenemos yo, y mis representados al Estacamento de terreno de Salitres que (ilegible) de la adjudicación que antecede, atendiendo (ilegible) el descubridor de éstos, y que no tenemos recursos como trabajarlos en el término de la Ley; y para que la presente tenga la fuerza necesaria nos separamos del dro. (derecho) que tenemos, y todo lo cedimos a favor del expresado D. Asencio Almonte, y queremos que la presente valga como judicial, como si (ilegible) contenía pasada en autoridad de cosa juzgada consentida y no apelada y

\footnotetext{
${ }^{46}$ ARTSNGM, Libro titulado: Nómina de oficinas Salitreras D.F. (delegación fiscal), Numerado 16. Año 1878. Fojas s/f
} 
pasa su valor, y (ilegible) lo firmamos con testigos en Pica a 28 de abril de 1851 años. A ruego de mi madre Doña Manuela Almonte y de las personas que representa firmo por ella. Fermina Almonte. Tgo. Miguel Lecaros. Tgo. Manuel Morales". ${ }^{47}$

A continuación, podemos analizar una información relevante respecto de las dificultades que las distancias planteaban en los procesos judiciales. Asencio Almonte reclama ante el Subprefecto de Tarapacá la urgente adjudicación de las estacas que Manuela Almonte le cedió:

"Asencio Almonte como mejor (ilegible) con bien me presento y digo: que el comisionado D. Francisco Luza, nombrado para poner en posesión de doce Estacas criadero de salitre, a Da. Manuela Almonte, como consta de la adjudicación que corre en el Expediente que acompaño, no ha podido tener efecto otra entrega en el dilato tiempo que date de esa fecha a la presente, a causa de que el ya citado comisionado, tiene formada su residencia a mucha distancia de Pica por lo que suplico a su juzgado nombre otra persona que cumpla con la comisión indicada, a mérito de que no sea por más tiempo perjudicado en la elaboración de salitre que trato de ejecutar. Por tanto. A US pido y suplico provea y mande según llevo pedido por ser de justicia Juro en dios no proceder con malicia y para ello etc. Tarapacá junio 7, 1851. Asencio Almonte". 48

Casi inmediatamente, el 9 de junio, la autoridad reemplazó al comisionado Luza por otro: Paulino Paniagua, quien actuaba desde Huantacondo (la localidad más próxima a Lagunas), pero se excusa por estar de viaje. De todas formas, se compromete en realizar lo solicitado por el Subprefecto de Tarapacá. Esta agilidad en la decisión política demuestra la importancia de Asencio:

Laguna Feb. $1^{\circ}$ de 1852.- En cumplimiento de la comisión que (ilegible). Yo el comisionado Paulino Paniagua puesto en este lugar la Laguna procedí a poner en posesión al ocurrente del terreno de Salitre de doce estacas en la Rinconada salar que se halla a [corte de pág.] de los intereses de los descubridores los mismos que [corte de pág.] amojonaron con sus correspondientes certificados, de [corte de pág.] puse en posesión a D. Asencio Almonte después [corte de pág.] practicado las demostraciones de verdadero dominio [corte de pág.] que tome dichas Estacas con lo que se concluyó este [corte de pág.] por mí y ante los testigos que suscriben de que certifico. Paulino Paniagua. Asencio Almonte. Tgo. Ignacio Arias. Tgo. Manuel Morales" 49 .

\footnotetext{
${ }^{47}$ ARTSNGM, Libro titulado: Nómina de oficinas Salitreras D.F. (delegación fiscal), Numerado 16. Año 1878. Fojas s/f ${ }^{48}$ ARTSNGM, Libro titulado: Nómina de oficinas Salitreras D.F. (delegación fiscal), Numerado 16. Año 1878. Fojas s/f ${ }^{49}$ ARTSNGM, Libro titulado: Nómina de oficinas Salitreras D.F. (delegación fiscal), Numerado 16. Año 1878. Fojas s/f
} 
Paulino Paniagua debió trasladarse a Lagunas, que entonces debió ser solo una pampa abierta a orillas del salar, para medir las doce estacas y solicitarle a Asencio que realizara "demostraciones de verdadero dominio". Estas acciones de dominio Asencio debió haberlas realizado muchas veces. Veamos solo un caso más de "cesión" de estacamentos a manos del descubridor y su compañía.

"Teresa de los Reyes, por mí, y a nombre de la familia que represento, hasta US me presento y digo: que en el lugar nombrado la Laguna, y en el que han descubierto criaderos de Salitres D. Asencio Almonte, y su compañía; se encuentra una Rinconada al norte de ésta, con un Salar a su frente, y como en el citado terreno, hay criaderos de Salitre; (ilegible) este lugar como punto cierto y determinado, para que en él, se digne la justificación de US, adjudicarme las Estacas que me correspondan, a mí, y mi familia que represento, compuesta de las personas siguientes: Manuela, Margarita, Narciso, Juan, Juana, Nicolas, Melchora, Eduviges, Manuela, Pabla, y (ilegible); prometiendo elaborar dichos terrenos, en el tiempo que juzgue conveniente de lo que resultara el bien Público, y particular; por tanto. A US pido y suplico, que, habiéndome por presentado, se digne proveer, lo que estimo de justicia. Juro no proceder con malicia, y para ello etc. Pica nov. 8, 1850. A ruego de Doña Teresa Reyes firmo yo por ella. Manuel Soto" ${ }^{50}$.

Resulta llamativo que este cartel es casi idéntico al de Manuela Almonte. De igual forma que se trate de mujeres que solicitan los estacamentos para ellas y sus hijos. Y, por cierto, la cesión de Teresa de su estacamento también es muy similar al de Manuela, a saber:

"Conste por la presente sesión que cedimos y pasamos a favor de D. Asencio Almonte el derecho que tenemos yo mis representados, al estacamento de terreno de salitres que consta de la adjudicación que antecede; atendiendo a que ha sido descubridor de éstos y que no podemos trabajarlos en el término de la Ley por falta de recursos; y para que la presente tenga la fuerza necesaria nos separamos del derecho, y todo lo cedemos a favor del expresado D. Asencio Almonte, y queremos que la presente valga como judicial, como si fuera sentencia pasa en autoridad de cosa juzgada consentida y no apelada y para su valor y fuerza la firmamos con testigos en Pica a 28 de Abril de 1852. A ruego de Doña Teresa Reyes y de las personas que representa firmo yo y por [corte de pág.]. Juan Lema y [corte de pág.]. Tgo. Juan Soto. Tgo. Rufino C. Reyes" ${ }^{51}$.

En este caso se trata de veintidós estacas de criadero de salitres, por tanto, su valor es más significativo. El mismo Paulino Paniagua fue quien le adjudicó oficialmente las estacas de Teresa

\footnotetext{
50 ARTSNGM, Libro titulado: Nómina de oficinas Salitreras D.F. (delegación fiscal), Numerado 16. Año 1878. Fojas s/f ${ }^{51}$ ARTSNGM, Libro titulado: Nómina de oficinas Salitreras D.F. (delegación fiscal), Numerado 16. Año 1878. Fojas s/f
} 
de los Reyes a Asencio Almonte, bajo el mismo argumento del comisionado oficial, Narciso Luza. Los testigos también fueron los mismos.

\section{El "descubridor" y los "otros cateadores"}

Como fue habitual en el proceso de explotación de la pampa salitrera, luego que el descubridor realizaba sus peticiones, comenzaban años después otros mineros a solicitar pedimentos en las proximidades de los linderos del primero. Ya no se trataba de familiares o amigos, sino de mineros y empresarios de la provincia, incluyendo extranjeros.

Veamos algunos de esos pedimentos a más de una década del "descubrimiento" de Asencio Almonte:

“De orden del señor diputado $2^{\circ}$ de minería de la provincia don Matías Hidalgo, ponemos en conocimiento público que el Dr. D. Federico Bockeham por sí y en representación de sus socios, se [ha] presentado ante nos los testigos que suscribimos, pidiendo se le adjudiquen sesenta estacas de terreno criaderos de salitre en el punto llamado la Laguna, terrenos descubiertos por don Asencio Almonte, siendo este pedimento a espaldas de los terrenos de don Manuel Almonte y Vigueras y cuyos linderos son: por el Norte los terrenos del expresado Almonte y Vigueras; por el Sur, con terrenos baldíos; por el Este con terrenos de don Matías Almonte, y por el Oeste con los intereses de don Asencio Almonte. La persona que se crea con mejor derecho se presentará dentro del término de noventa días a deducir su derecho que será oído en justicia. Calacala octubre 5 de 1867. Tgo. Loreto Gonzales. Tgo. Eugenio Carpio" ${ }^{52}$.

El Dr. Federico Bockenham era una persona muy conocida entonces, su residencia estaba en la capital de la provincia: San Lorenzo de Tarapacá. Su casa fue descrita por el investigador inglés William Bollaert y posteriormente por el historiador Óscar Bermúdez ${ }^{53}$.

Federico Bockenham estaba emparentado, con uno de los mineros de la plata más conocidos y que posteriormente derivó al salitre: Atanacio Tinajas. Hermano de su esposa María Tinajas. La familia Tinajas tenía vínculos con los Zavala y éstos con los Almonte, por lo que podemos suponer que, con Bockenham, se continúa con la estrategia empresarial de Asencio Almonte. $Y$, posiblemente, todos formaban parte de la "Compañía" de Asencio Almonte.

En la petición el Dr. Bockenham no solo reconoce el carácter de "descubridor" a Asencio Almonte, sino que también hace referencia al sobrino de éste: Manuel Almonte y Vigueras. Al hacer su pedimento a las espaldas del terreno de los Almonte, permite ampliar el estacamento inicial, posiblemente con el propósito implantar una máquina.

\footnotetext{
52 El Mercurio de Tarapacá N 300 Año XI, octubre 19 de 1867, p.4.

${ }^{53}$ Bermúdez, Óscar 1963. Op. Cit., p. 117.
} 
En el siguiente inserto en el principal periódico de la provincia, publicado el mismo día que el anterior, vemos un cartel solicitado por Almonte y Vigueras:

“De orden del señor diputado $2^{\circ}$ de minería de la provincia don Matías Hidalgo, ponemos en conocimiento público que D. Manuel Almonte y Vigueras, se ha presentado, por sí y su compañía y por ante nos los testigos que suscribimos, pidiendo que se le adjudiquen sesenta estacas de terreno criadero de salitres que ha encontrado baldíos al Sur de la provincia en el punto llamado Laguna y que se encuentra bajo los linderos siguientes: por el Sur con terrenos baldíos; por el Norte, con el salar de la Laguna, por el Este con terrenos de don Asencio Almonte, y por el Oeste con terrenos del finado D. Matías Almonte. La persona que se crea con mejor derecho se presentará dentro del término de noventa días a deducir su derecho que será oído en justicia, Calacala octubre 5 de 1867. Tgo. Loreto Gonzales. Tgo. Eugenio Carpio". ${ }^{54}$

A continuación, leamos un cartel que salió pocos días después en el mismo periódico, solicitado por Carlos Gallagher, de quien no tenemos antecedentes de vínculos familiares o comerciales con los Almonte, pero se trata de un interesante personaje que tendrá un papel clave en la década siguiente en el proceso de expropiación de la industria del salitre ${ }^{55}$.

“De orden del señor diputado $2^{\circ}$ de minería de la provincia don Matías Hidalgo, ponemos en conocimiento público que D. Carlos Gallagher por sí y en representación de su compañía, se ha presentado pidiendo se le adjudiquen sesenta estacas de terreno criadero de salitre que se encuentran baldíos en el punto llamado la "Laguna" al S.O. de los terrenos conocidos como el Sud. Encontrándose bajo los linderos siguientes: por el Este y Sud con los intereses del descubridor D. Asencio Almonte, por el Norte con los terrenos realengos, y por el Oeste terrenos del mismo modo. La persona que se crea con mejor derecho se presentará dentro del término de noventa días a deducir su derecho que será oído en justicia. Calacala octubre 5 de 1867. Tgo. Loreto Gonzales. Tgo. Eugenio Carpio". ${ }^{56}$

Por último, incluimos un Cartel de Asencio:

“De orden del señor diputado $2^{\circ}$ de minería D. Matías Hidalgo, ponemos en conocimiento del público, que D. Asencio Almonte, por sí y en representación de sus socios, se ha presentado, pidiendo que se les adjudique setenta estacas de terreno de criadero de salitre

\footnotetext{
${ }^{54}$ El Mercurio de Tarapacá N 300 Año XI, octubre 19 de 1867, p.4.

55 Entre 1875 y 1879, Gallagher fue representante o agente -en Tarapacá- de los Bancos Asociados. Se definía como soltero, comerciante y de Iquique. No era un funcionario de gobierno, ese papel lo cumplía el cajero fiscal, se trataba de un empleado de los bancos encargados de la expropiación. Carlos Gallagher, se adaptó rápidamente a la administración chilena, pues siguió involucrado exitosamente a esta industria.

${ }^{56}$ El Mercurio de Tarapacá ํ3 301, año XI, 26 octubre 1867, p. 4.
} 
que se encuentra en el punto nombrado Laguna, y a continuación y espaldas, de los terrenos pedidos por la señora Da. Teresa Reyes, cuyos linderos son: por el Sur, los terrenos de la señora Reyes; por el Oeste, Norte y Este, con terrenos baldíos. La persona (...) Calacala ${ }^{57}$ octubre 5 de 1867. Tgo. Loreto González Tgo. Eugenio Carpio"58.

El hecho que estos pedimentos se hayan realizado el mismo día (5 de octubre de 1867), es un claro indicio que se trató de una estrategia para alcanzar un gran número de estacas para implantar una oficina salitrera de Máquina. No se trataba solamente de Almonte y su familia, sino de una sociedad. El día 23 de octubre de ese mismo año, se le entregaron otras setenta estacas denunciadas directamente por Asencio Almonte.

Esta operación de Asencio Almonte permite suponer que respondieron a un proyecto empresarial que estaba en marcha. Dos años después hubo una denuncia en contra de Almonte por irregularidades en la adjudicación de terrenos en Lagunas, Lagunilla y Llamara. Su denunciante fue uno de los supuestos afectados, Miguel Montecinos.

“D. Asencio Almonte:

Se previene a quien pueda interesar; que cualquiera arreglo que D. Asencio Almonte haga sobre los terrenos de salitre de "Laguna", "Lagunilla" o "Llamara" adolecerá de nulidad, por cuanto hay pleitos pendiente sobre dichos terrenos con José María Villegas, Pedro José Soto, Manuel M. Salvatierra, D. Melchor Riveros y el que suscribe.

Iquique, julio 30 de $1870^{\prime \prime 59}$.

No demoró en responder Asencio a través de un inserto en el periódico bajo el título de "contra-aviso", bajo los siguientes argumentos:

"El abajo suscrito, en vista de una nota maliciosa puesta por D. Miguel Montecinos en este diario $\mathrm{N}^{\circ} 414$ fecha 6 del corriente, se limita ante el público en contestar que al ocuparse de arreglos sobre terrenos de su exclusiva legal pertenencia, situados en la parte Sur de esta Provincia, obra sin temor alguno, por las pretensiones infundadas de D. Miguel Montecinos y demás. Iquique, 10 de agosto de 1870".

Sin embargo, a pesar de la displicente respuesta de Almonte, que suele tener por base la razón o el poder, no amilanó a Montecinos, quien en su segunda denuncia incluyó a otros nombres de mayor prestigio social o político, además profundizó en sus argumentos:

\footnotetext{
57 De este lugar se tiene memoria de la oficina Cala Cala, que formaba parte del Grupo Nebraska, y desaparecida junto a Santa Laura, Santiago Humberstone, Peña Chica y el campamento don Guillermo en la década de 1950. Sin embargo, en la década de 1860 era un poblado similar al de Cocina, Yungay y otros.

58 El Mercurio de Tarapacá ํㅜ 301, año XI, 26 octubre 1867, p. 4.

${ }^{59}$ El Mercurio de lquique $\mathrm{N}^{\circ} 414$, año XII, 6 de agosto de 1870, p. 4.
} 
"En el número anterior del periódico de UU. Ilamé la atención de los interesados en los terrenos, de salitre de "Laguna", "Lagunillas" y "Llamara", asegurando que esos terrenos se hallaban en pleito. Como a pesar de eso, insiste, D. Asencio en hacer contratos en referencia a esos terrenos, creo que los siguientes datos harán conocer, de cuánto es capaz D. Asencio a este respecto.

Cuando denuncié los terrenos que indico, D. Asencio Almonte presentó al Diputado, entonces (D. Matías Hidalgo) unos escritos de denuncia de años anteriores, de varias personas, como D. José M. de Loayza, D. Santiago Zavala, D. N. Fuente, etc. transferidos a D. Asencio Almonte; pero en cuya transferencia aparecían falsamente las firmas de los primeros denunciantes. El hecho de esta falsificación se hizo público, y el Sr. Santiago Zavala, cuya firma fue una de las falsificadas (según se decía públicamente) interpuso querella criminal ante el juez de derechos entonces Dr. D. Vicente Arce, y este admitiendo la querella, dirigió un oficio al Diputado Sr. Hidalgo para que los documentos falsificados figuraran en el proceso. En este estado se ausentó el Sr. Dr. Arce y el Diputado Sr. Hidalgo de este puerto y la querella quedó paralizada.

Ahora, se asegura que D. Ascencio Almonte ha hecho protocolizar unos documentos relativos a esos terrenos y que con ellos se propone grandes negocios. Los documentos (si son los falsificados en opinión general) no han podido protocolizarse legalmente, como por los pleitos pendientes sobre los terrenos de salitre a que se refieren.

Si se duda de lo que expongo, consúltese el testimonio del Dr. D. Vicente Arce, del Sr. D. Matías Hidalgo, del Sr. D. Santiago Zavala, de los actuarios que concurrieron a la diputación de Minería y de cuantos han tenido ocasión de ver aquellos documentos.

lquique, agosto 11 de $1870^{\prime \prime 60}$.

Los "grandes negocios" que se refiere Montecinos eran los que acordará con la Compañía Esperanza, como veremos más adelante. Cuando Almonte se vea compelido a vender al gobierno peruano bajo la ley de expropiación, todas las irregularidades que pudieron existir en la conformación de su estacamento serían detectadas por las comisiones de ingenieros y de abogados.

Las peticiones de 1867 se realizaron diecisiete años después de los primeros pedimentos de Asencio Almonte, porque ya se suponía que se terminaría la libertad de cateo. En 1868 fue prohibido por el gobierno de José Balta el cateo libre como el realizado por Almonte y socios.

A todas las estacas antes mencionadas, se deben sumar doscientas ochenta y seis en Lagunas que acordó Asencio con Toribio Caucoto, con fecha 4 de octubre de 1850. Las que fueron remensuradas en 1867 por Almonte. También realizó una permuta de estacas con su sobrino Manuel Almonte y Vigueras: Asencio le transfirió cuarenta estacas a Manuel, que

${ }^{60}$ El Mercurio de Iquique $\mathrm{N}^{\circ} 415$, año XII, 13 de agosto de 1870, p. 4 
estaban sita en una pampa llamada "Ascensión", y Manuel hizo lo propio con sesenta estacas en Lagunas.

Otra transacción intrafamiliar fue la que hicieron los hermanos Miguel y Francisco Almonte, sobrinos de Asencio. Le vendieron cincuenta y cuatro estacas que habían recibido de su padre, Matías Almonte de La Fuente, ubicadas también en Lagunas. Esta venta fue realizada el 8 de abril de 1873.

El hermano de Asencio, Matías Almonte de La Fuente, como hemos visto, fue incluido en algunos pedimentos en Lagunas. Era también dueño de sesenta estacas de salitre en el cantón Bellavista, al sur de la provincia de Tarapacá, de 50 estacas en "Ascensión", y otros terrenos salitrales en el cantón de La Noria ${ }^{61}$.

El hecho que haya nacido en San Francisco de Chiu-Chiu, un poblado colonial ubicado en la cuenca intermedia del río Loa, nos abre una puerta muy interesante para explicar la familiaridad de los Almonte con los circuitos de arrieros provenientes de Bolivia y el noroeste argentino, hasta alcanzar a Quillagua, Huatacondo y Pica, cuya profundidad histórica es precolombina.

Los investigadores Francisco Gallardo y Carolina Odone nos entregan una información que tiene sustento etnohistórico sobre este espacio de la cuenca del río Loa:

“Este oasis (Quillagua), al igual que otros espacios del Loa medio y superior y del área PicaGuatacondo, formaba parte de una malla de articulación de zonas productivas complementarias que posibilitó que las poblaciones indígenas que las habitaban, en este caso picas-tarapacá y atacamas, accediesen a una amplia gama de recursos y productos que se encontraban a distancia y ubicados en ambientes diferenciados, aun en tiempos coloniales" ${ }^{\prime 62}$.

Los Almonte eran originarios de Pica y el abuelo de Asencio fue minero en Tamentica, en el sector de Huatacondo, lo que familiarizó a esta familia con ese eje Pica-Huatacondo, y con el Loa superior. Cuando Gregorio Almonte y Quiroga y Melchora de la Fuente y Palacios decidieron radicarse en Chiu Chiu, todavía eran tiempos coloniales. Esa decisión familiar permitió que los Almonte recorrieran el camino donde estaban los salares de Lagunas.

Matías fue el único que nació en San Francisco de Chiu Chiu, lo que indica que Gregorio y Melchora regresaron a Tarapacá, posiblemente a Pica, que era el centro económico, social, cultural y familiar más importante de la provincia. San Lorenzo de Tarapacá solo le superaba en importancia política.

\footnotetext{
${ }^{61}$ Archivo Notarios de Tarapacá [ANT], tomo IX, 1871.

62 Gallardo, Francisco. y Odone, María Carolina. 2019."El oasis de Quillagua: una nota sobre fronteras entre Picas y Atacamas (río Loa inferior, períodos intermedio tardío y colonial tardío, norte de Chile)", en Revista Antropologías del Sur, Santiago, $N^{\circ} 12$, año 6:175-187, p. 176.
} 
Este hermano, un año mayor que Asencio, se casó con Manuela Almonte Olazábal, hija de José Antonio de Almonte y Salazar y de Ascencia de los Reyes Olazábal. Uno de sus estacamentos de Matías se denominó "Ascensión", no sabemos si fue por su suegra o por su hermano.

Matías y Manuela tuvieron tres hijos: Francisco, Miguel y Benjamín. Este dato de los hijos descarta que ella sea la Manuela Almonte que aparece en uno de los carteles de pedimientos en Lagunas ya citado con anterioridad. El temprano fallecimiento de Matías llevó a sus hijos a poner en venta en 1871, con la ayuda de su influyente primo Manuel Almonte y Vigueras, el estacamento de propiedad de Matías y que bautizó con el nombre de "Ascensión".

"Señor Escribano Público de la Provincia.

Sírvase Ud. extender en su registro de escrituras públicas un poder general que otorgamos a nuestro Primo Don Manuel Almonte y Vigueras, para que representando nuestras propias personas, acciones y derecho proceda o venda ya sea en esta República o en el extranjero nuestros estacamentos de salitres que tenemos en esta Provincia, y que constan de cincuenta y cuatro estacas que tenemos en el sur y sitio conocido con el nombre de la Laguna, las mismas que heredamos de nuestro finado padre don Matías Almonte de la Fuente, y cincuenta estacas en el punto conocido con el nombre de la Ascensión, cuyos títulos le hemos entregado en esta fecha, previéndose que en cuanto a precio de dichos intereses para su venta lo dejamos a juicio de nuestro apoderado, a cuyo efecto le hemos dado nuestras instrucciones verbales. Así mismo, le autorizamos para que en el caso que no se practique la venta indicada pueda formar una o más Compañías para trabajar dichos intereses, para lo cual le conferimos, libre, franca y general administración para cuanto fuese necesario hacer. Usted Señor Escribano se servirá agregar todas las demás cláusulas y condiciones de ley que hagan eficaz y valedero el presente poder. Iquique mayo primero de mil ochocientos setenta y uno. Francisco Almonte. Miguel Almonte" ${ }^{63}$.

Manuel Almonte y Vigueras, a pesar de que era hijo del menor de los hermanos Almonte de la Fuente, se transformó con el tiempo en más destacado de toda la familia, incluyendo al propio Asencio.

La historia del salitre ha destacado a Asencio Almonte fundamentalmente por la operación comercial que realizó con la Compañía Salitrera Esperanza. Aquí hemos querido destacar su importancia como cateador y descubridor.

${ }^{63}$ ANT. Iquique, Vol. 9, a fojas 385, 1871. 


\section{La Sociedad La Esperanza y Asencio Almonte}

Como adelantamos, Asencio Almonte era primo de uno de los "próceres" tarapaqueños: Antonio Gutiérrez de la Fuente. Antonio ocupó varios cargos incluyendo -durante el periodo de Agustín Gamarra- la presidencia de Perú y, después, la senaduría por Tarapacá. Se destacó en la lucha en contra de la confederación de Andrés de Santa Cruz, llegando ser nombrado Gran Mariscal de Arequipa.

Los Gutiérrez de la Fuente de Tarapacá ${ }^{4}$ y sus primos los De la Fuente de Arequipa siempre se mantuvieron vinculados a través de la minería de la plata. Esa práctica minera continuó con el salitre y surgió una sociedad entre Antonio y Asencio. Guillermo Billinghurst, nos dice que:

"el 14 de septiembre de 1870, se organizó en Lima, una sociedad anónima, con un capital de 50.000 soles, bajo la denominación "Empresa Salitrera Esperanza", para explotar unos yacimientos que tomó por arrendamiento por el término de diez años, y que se hallan situados en el extremo sur de la Provincia de Tarapacá, en cantón de Lagunas" ${ }^{65}$.

Debido a la lejanía de este cantón del puerto de Iquique, la Compañía Esperanza proyectó su puerto en embarque en Patillos, y fijó allí su dirección. Esta decisión la obligaba negociar con la empresa ferroviaria Montero Hnos. que, por una ley del 11 de julio de 1868, tenía el monopolio de la construcción de los ferrocarriles en Tarapacá.

Sobre la base de 408 estacas de criadero de salitres de Asencio Almonte se formó la Compañía Salitrera La Esperanza. El artículo Primero de esta escritura señalaba:

"Art. $1^{\circ} \mathrm{El}$ señor don Asencio Almonte, dueño y actual poseedor de cuatrocientas ocho estacas de intereses salitreros, en los terrenos denominados de la "Laguna", en el distrito de "Pica", provincia de Tarapacá, cede y traspasa dichos terrenos, por el término de diez años, que empezará a contarse desde el día que se empiece a elaborar salitre para beneficiarlo y exportarlo en favor y utilidad de la compañía que forma hoy, en virtud de la presente escritura, con los señores Gran Mariscal don Antonio Gutiérrez de la Fuente, coronel don José Pérez de Vargas, coronel don Juan Antonio Torrico, don José Amancio Castillo, don José Gregorio Basagoitia, don Antonio Dañino y don Julián de Zaracondegui”66.

El entusiasmo de estos socios se debía no solo al grande y rico estacamento de propiedad de Asencio Almonte, sino también el aprovechamiento de los privilegios de la Compañía

\footnotetext{
${ }^{64}$ Calixto Gutiérrez de La Fuente, hermano de Antonio, fue Subprefecto de Tarapacá y uno de los firmantes del Acta de Independencia del Perú.

65 Billinghurst, Guillermo 1905. Documentos relativos al Ferrocarril de Patillos. Recopilados por Guillermo E. Billinghurst, Valparaíso Sociedad Imprenta y Litografía Universo, p. iv.

66 Billinghurst, Guillermo. 1889. Documentos relativos a la Salitrera "Lagunas" recopilados por Guillermo E. Billinghurst, Santiago, Imprenta de El Progreso, p. xxv.
} 
Ferroviaria Montero Hnos., que daba la certeza de éxito. En octubre de 1871 firmaron un contrato para la construcción de un ferrocarril de trocha angosta entre el puerto de Patillos y las salitreras de Lagunas. Representó entonces a la Sociedad de La Esperanza, en calidad de presidente de su directorio, Julián de Zaracondegui. Mientras el socio Antonio Dañino fue elegido para asumir la dirección y administración de la empresa, teniendo por tarea de dirigir las obras de plantificación y construcción de la industria, así como los trabajos para el transporte y embarque del salitre. Tenía además por obligación residir en el lugar de los trabajos, recibiendo un sueldo de doscientos pesos, el que cesaría cuando la empresa comenzara a recibir utilidades.

El Banco de Lima financiaría el ferrocarril. No sabemos el desempeño de Antonio Dañino en su tarea de implantar la máquina de elaboración de salitres, pero cuando se vendió "Lagunas" al Gobierno del Perú, se pagó más por la máquina que por el estacamento.

No entraremos a profundizar en el fracaso de esta Compañía y menos en los litigios posteriores, porque es uno de los capítulos más estudiados de la industria del salitre y que ha generado mucha controversia, porque nos aleja de Asencio Almonte.

Podemos decir que las líneas férreas que partían en el puerto de Patillos nunca llegaron hasta Lagunas. Precisamente, ese fue uno de los problemas, la línea por construir alcanzaba los 110 kilómetros, porque antes de llegar a Lagunas pasaba por Bellavista. La distancia real entre Lagunas y Patillos era de 78 kilómetros. ¿Por qué debía este ferrocarril pasar por Bellavista, cruzando la pampa Tente en el Aire, dando una vuelta que aumentaba aproximadamente en un tercio las líneas férreas? La respuesta puede ser que se aprovechaba la inversión para pasar por Buenaventura, Alianza y otras oficinas que estaban implantándose. Alianza ya se perfilaba en una de las más grande de todas en Tarapacá ${ }^{67}$.

El gobierno peruano le compró a Almonte los terrenos salitrales de Lagunas por escritura pública de 11 de octubre de 1876, es decir, antes que se cumplieran los diez años señalados en la escritura que formó la Compañía Salitrera La Esperanza. La venta fue exitosa, se reconoció un total de 548 estacas salitreras y no las 408 de que se tenía registro. ¿Habrá influido su primo Antonio Gutiérrez de la Fuente?, o, ¿su socio Carlos Gallagher, quien era el representante de los bancos limeños que realizaron el proceso de expropiación de la industria salitrera?

Veamos algunos fragmentos de esa compraventa de "Lagunas" entre Asencio y el Gobierno del Perú, en Lima a 11 de octubre de 1876.

[...] Don Asencio Almonte, propietario de quinientas cuarenta y ocho estacas en el sitio llamado "Lagunas", y con derecho en el establecimiento salitrero denominado "La

\footnotetext{
67 No debemos olvidar que los Almonte, especialmente Manuel Almonte y Vigueras, tenían intereses en Bellavista, sin embargo, sabemos también que éste aparentemente estaba dedicado en esa década a la agricultura en su hacienda Curaña, después de haber tenido un papel protagónico en la revolución de 1868.
} 
Esperanza" según aparece de la escritura celebrada por dicho Almonte con la Sociedad "La Esperanza" en catorce de Setiembre de mil ochocientos setenta cuyo testimonio corre en el expediente del contrato celebrado por el Supremo Gobierno, con la referida Sociedad "La Esperanza" y que remitió a Ud. para que extendiera la escritura de aceptación que consta del expediente adjunto compuesto de la tasación hecha por los ingenieros del estacamento y derechos de Almonte; de la solicitud de éste ofreciendo en venta al Gobierno sus terrenos y acciones en la Sociedad "La Esperanza" de la Suprema resolución de veinticuatro de Julio último, por la que el Gobierno, acepta el ofrecimiento de venta de las quinientas cuarenta y ocho estacas, de los derechos de Almonte en la sociedad, conviene pagar el precio de noventa mil soles (s/. 90.000) por todo [...]. ${ }^{68}$

Asencio Almonte se comprometió con el Gobierno del Perú a ceder y transferir todos sus derechos y acciones que celebró con la sociedad "La Esperanza". Lo más significativo para este hombre debió haber sido que entregaba en Lima más de veinte años de trabajo en el desierto de Tarapacá, como cateador, minero y comerciante.

Con relación a la diferencia de estacamentos que hemos señalado, la siguiente minuta explica ese diferencial:

"Certificado. A fojas seiscientas veinte registro de Hacienda corriente y con fecha ¿ं? de Octubre de mil ochocientos setenta y seis el Señor Don Asencio Almonte ha vendido al Supremo Gobierno quinientas cuarenta y ocho estacas de su propiedad en el sitio denominado "Lagunas" en la provincia de Tarapacá de las cuales cuatrocientas ocho fueron objeto del contrato que aquel celebró con la Sociedad "La Esperanza" y las ciento cuarenta restantes contiguas a las anteriores, como también [...]." ${ }^{\prime 69}$

Asencio Almonte recibió un pago por sus derechos sobre la totalidad del estacamento de 548 estacas de noventa mil soles, prácticamente un $10 \%$ de lo pagado a la Compañía La Esperanza. Es decir, esta Compañía recibió del Gobierno del Perú en total 990.000 soles, de los cuales 90 mil fueron para Almonte. De estos 900.000 soles, 500.000 el gobierno peruano los pagó por los derechos del ferrocarril de Patillos. La Compañía La Esperanza debió recibir 310.000 soles, lo que incluía todas las inversiones, especialmente la Planta de elaboración de salitres. Este monto se explicaría porque -según Billinghurst- hacia 1874 poseía una Máquina que tenía una facultad productiva de 360.000 quintales españoles anuales ${ }^{70}$. Los Bancos Asociados, que representaban al gobierno, a través de sus comisiones de abogados e ingenieros

\footnotetext{
ARTSNGM, Libro titulado: Delegación Fiscal de Salitreras. Expediente de Montero con la Compañía Salitrera "La Esperanza". Numerado 20 y 20 bis. Año: noviembre 9 de 1875. Fojas s/f

${ }^{69}$ ARTSNGM, Libro titulado: Delegación Fiscal de Salitreras. Expediente de Montero con la Compañía Salitrera "La Esperanza". Numerado 20 y 20 bis. Año: noviembre 9 de 1875. Fojas s/f

${ }^{70}$ Billinghurst, Guillermo 1889. Los capitales salitreros de Tarapacá, Santiago, Imprenta El Progreso, p. 16.
} 
valoraban mucho la existencia de máquinas de elaboración de salitre. De hecho, el pago realizado por "Lagunas" fue el segundo más alto de todas las oficinas salitreras de Máquina vendidas al gobierno peruano, solo después de la Compañía Salitrera de Tarapacá, que en rigor era nada menos que la Casa Gibbs, dueña de las oficinas Limeña y Carolina, las que se vendieron en 1.250 .000 soles.

El geógrafo Francisco Riso Patrón, nos pueden llevar a error o confusión. Riso Patrón nos dice sobre Lagunas que, "las 548 estacas, tasadas por el Gobierno del Perú en 90.000 soles plata y vendidas a éste por Asencio Almonte, recibiendo en pago 9 certificados de la serie $A^{\prime \prime 1}$. Con esos certificados, a partir de 1882, ya era posible rescatar "Lagunas" depositándolos en la Jefatura Política de Tarapacá. ¿Quién realizó el rescate?

Para 1878, la salitrera no era conocida como "Lagunas" sino "La Esperanza", nombre muy irónico, considerando los proyectos fracasados que no pudieron exportar de nitrato de soda por el frustrado puerto salitrero de Patillos. Lo tenían todo para ser una de las "grandes" Compañías salitreras y los litigios superaron el emprendimiento, pero esa es otra historia.

Antonio Gutiérrez de la Fuente que falleció en 1878 a la edad de 81 años, cuando los certificados peruanos todavía devengaban intereses, no supo del fracaso del préstamo internacional que cubriría la compra de las salitreras ni de la Guerra del Pacífico. Su último cargo de responsabilidad política fue de Senador por Tarapacá. Asencio, en cambio, sí fue testigo de todos esos acontecimientos históricos.

Asencio Almonte vendió sus títulos al ciudadano chileno de origen norteamericano, Eduardo Délano, quien rescataría "Lagunas" al depositar todos los certificados ante la Jefatura Política de Tarapacá el 22 de mayo de 1882. En ese momento el Jefe Político de Tarapacá, era Rafael Segundo Sotomayor.

A su vez, Eduardo Délano vendió "Lagunas" al "rey del salitre", John Thomas North, el 11 de septiembre de 1888. North también se apoderó del ferrocarril de Patillos a Lagunas. En 1874 se había constituido en Lima la Compañía Nacional de los Ferrocarriles Salitreros del Perú para ejecutar los privilegios recibidos por Montero Hnos. de parte del Estado peruano en decretos del 11 de julio de 1868 y el 18 de mayo de 1869 y 26 de octubre de 1871, para construir y explotar las líneas férreas entre los puertos y las salitreras de Tarapacá. El 4 de octubre de 1888, la Compañía Nacional de los Ferrocarriles Salitreros del Perú le cede los derechos a la Compañía de Ferrocarriles Salitreros de Tarapacá, más conocida como Nitrate Railways $C^{\circ}$. Ltda, de propiedad de J.T. North.

North es dueño del ferrocarril entre Patillos y Lagunas para no hacerlo funcionar nunca. Las líneas férreas quedarían expuestas al tiempo y a los elementos de la naturaleza del desierto.

\footnotetext{
${ }^{71}$ Riso Patrón, Francisco 1890.Diccionario Geográfico de las Provincias de Tacna y Tarapacá, Iquique, Imprenta de La Industria, p.50.
} 
J.T. North formó dos compañías, a saber: The Lagunas Syndicate Ltd., propietaria de las salitreras North y South Lagunas, y The lagunas Nitrate co. Ltd., dueña de las oficinas Central Lagunas y Trinidad.

Cabe agradecerle a J.T. North que, en todas las Compañías salitreras que organizó, siempre conservó los antiguos nombres de las oficinas o estacamentos que compró, lo que impidió que fueran olvidados y, en algunos casos, gracias a su iniciativa empresarial se consolidaron como fue con Lagunas. En general los ingleses tuvieron ese gesto importante, pues empresarios salitreros de otras nacionalidades -como por ejemplo croatas y españoles- solían cambiar los nombres originales por otros alusivos a sus orígenes. Vimos el caso del estacamento "San Rafael" que se transformó en la oficina "Granja”, de propiedad del español Matías Granja.

Con las tres "Lagunas" se consolidó el cantón de ese nombre. "Lagunas" ya no era solo un punto, un estacamento o una pampa, sino un cantón salitrero. Nacería también un puebloestación, que tuvo una larga vida en el siglo XX. Golpeado por las recurrentes crisis económicas, la desaparición del ferrocarril salitrero, y la lenta marcha del longitudinal, marcaron su total abandono. Al quedar algo retirado del camino Panamericano o ruta 5 Norte, expresión de la nueva modernidad del siglo XX, el pueblo-estación de "Lagunas" se fue quedando definitivamente solo, con excepción de su más fiel habitante: Amable Chávez Albornoz, quien vivió allí hasta el 5 de marzo de $2015^{72}$.

Quiero, a través de la memoria de don Amable Chávez Albornoz, hacer un homenaje a todas las personas que vivieron, disfrutaron y sufrieron en el cantón Lagunas, ese territorio al borde de un salar que nació gracias al descubrimiento de un enorme "criadero de salitres" realizado por el ojo cateador de don Asencio Almonte de la Fuente en 1850.

En la actualidad, las ruinas de las tres oficinas salitreras del cantón Lagunas están en peligro de desaparecer para siempre.

\section{Conclusiones}

La historiografía regional y nacional, tanto peruana como chilena, han destacado a personajes como José Basilio de la Fuente, el minero de la plata más acaudalado y poderoso de Tarapacá en el siglo XVIII, ${ }^{73}$ igualmente la figura del Gran Mariscal Antonio Gutiérrez de la Fuente, debido a su importancia política y militar en el proceso de consolidación de la república del Perú, ${ }^{74}$ al pionero salitrero Matías de la Fuente y Palacioss ${ }^{75}$, al prefecto de Tarapacá y salitrero Manuel

\footnotetext{
72 Agradezco esta información a Sergio Chávez Rubelma, hijo de don Amable.

73 Hidalgo, Jorge y González, Soledad 2019. El testamento de Josef Basilio de la Fuente. Sociedad, riqueza y redes de poder en Tarapacá, siglo XVIII. Qillqa Ediciones UCN, Antofagasta.

${ }^{74}$ Aljovín, Cristóbal 1996. Violencia y legitimidad. Las revoluciones entre 1827 y 1841, en Apuntes № 39, Lima, pp. 113-127.

75 Bermúdez, Óscar 1963. Historia del salitre. Desde sus orígenes hasta la guerra del Pacífico, Santiago, Ediciones de la Universidad de Chile,
} 
Almonte y Vigueras, por sus estrechos lazos políticos y de amistad con el prócer Ramón Castilla Marquesado, y porque su salitrera La Palma es actualmente patrimonio histórico de la humanidad. ${ }^{76} \mathrm{El}$ primero de los personajes era bisabuelo de Asencio Almonte de la Fuente, el segundo su primo, el tercero su tío y el cuarto su sobrino. Las historiografías política y económica tradicionales encontraron suficientes argumentos para destacarlos, dejando bajo un manto de olvido a muchos otros que, por detalles de los acontecimientos no fueron resaltados, precisamente por una historiografía "acontecimental" 77 que suele quedarse en sucesos específicos, sin rescatar los procesos o el desenvolvimiento de las sociedades.

Asencio Almonte no es menos relevante que sus parientes señalados. Su riqueza no alcanzó las dimensiones de su bisabuelo, pero él -a diferencia de Basilio-fue un descubridor y, a partir de su descubrimiento, se desarrollaron tres oficinas, un pueblo y un cantón salitreros, y el nombre "Lagunas" persiste hasta nuestros días. No estuvo en batallas decisivas ni ocupó por un breve tiempo el sillón presidencial como el Gran Mariscal, pero hasta el propio Antonio se interesó en formar parte de la sociedad que explotó Lagunas. Tampoco presenció el último aliento del prócer Ramón Castilla en Retamilla como su sobrino, en cambio Manuel se forjó como minero al lado de Asencio.

Asencio Almonte fue un minero que tuvo rasgos similares a los otros contemporáneos que, como él, se adentraron en el desierto y enfrentados a los elementos lograron sus objetivos o quedaron arruinados. Asencio, como la mayoría vieron la plantificación de Paradas salitreras en su estacamentos y, como una minoría, también supo de la plantificación de una máquina de vapor en Lagunas.

Muchos de los mineros tarapaqueños que alcanzaron sus metas fueron arruinados después por las deudas contraídas con los habilitadores. Asencio logró sortear ese problema, pero no fue capaz, como la mayoría de sus pares, de consolidarse como empresario minero salitrero durante el periodo chileno. Algunos lo lograron, como Antonio Ceballos, los hermanos Quiroga, los hermanos Ossio, Juan L. Loayza, Juan Vernal y Carpio, entre otros. Es decir, Asencio encarna a un tipo de minero que marcó una época del desarrollo de la industria del salitre.

\section{Referencias citadas}

\section{Bibliografía}

Aljovín, Cristóbal. 1996. Violencia y legitimidad. Las revoluciones entre 1827 y 1841, Lima, Apuntes Nㅜ 39.

\footnotetext{
76 Ojeda Berger, Orietta 2017. "La antigua Palma y la actual Humberstone. Un complejo patrimonial y un paisaje cultural pampinos", en Tiempo Histórico, Santiago, № 14, pp.15-36.

77 Rivero, Francisco 2013. "El devenir del acontecimiento en la operación historiográfica", en Historia y Grafía, año 21, № 41, Ciudad de México, pp. 43-77.
} 
Alvarado, Margarita. 2002. "La imagen de lo no vivido. Memoria y fotografía de las salitreras del norte de Chile", en Revista Aisthesis, №35, Santiago, pp. 41-49.

Arce, Isaac. 2004. Narraciones históricas de Antofagasta, Antofagasta, Corporación Pro Antofagasta (edición original 1930).

Bateson, Gregory. 2002. Espíritu y naturaleza, Buenos Aires, Amorrortu Editores.

Bermúdez, Óscar. 1963. Historia del salitre. Desde sus orígenes hasta la guerra del Pacífico, Santiago, Ediciones de la Universidad de Chile.

Billinghurst, Guillermo. 1889. Los capitales salitreros de Tarapacá, Santiago, Imprenta El Progreso.

Billinghurst, Guillermo. 1905. Documentos relativos al Ferrocarril de Patillos. Recopilados por Guillermo E. Billinghurst, Valparaíso, Sociedad Imprenta y Litografía Universo.

Billinghurst, Guillermo. 1889. Documentos relativos a la Salitrera "Lagunas" recopilados por Guillermo E. Billinghurst, Santiago, Imprenta de El Progreso.

Bravo Elizondo, Pedro y González, Sergio. 1994. Iquique y la pampa. Relaciones de corsarios, viajeros e investigadores 1500-1930, Iquique, Ediciones TER.

Carmona, Javier. 2018. "Alfalfa y minería en el desierto surandino", en Revista chilena de Antropología, $\mathrm{N}^{\circ} 37$, Santiago, pp. 213-229.

González, Sergio. 2002. Hombres y mujeres de la pampa. Tarapacá en el ciclo de expansión del salitre, Santiago, Editorial LOM.

González, Sergio. 2004. "La lixiviación cultural del hombre y el desierto (1830-1930): la transformación del desierto en pampa y del enganchado en pampino", en Revista Polis, N 9, vol. 3, Santiago, pp. 319334.

González, Sergio. 2005. "La crítica a la máquina surgida durante el ciclo del salitre", en Revista Diálogo Andino, №21, Arica, pp. 125-131.

González, Sergio. 2013. “Heterotopía y utopía en la pampa salitrera. Desde los mitos de la ocupación del desierto y del descubrimiento del salitre a la urbanización de la pampa, 1870-1920", en González, Sergio. La Sociedad del Salitre. Protagonistas, migraciones, cultura urbana y espacios públicos, Santiago, RIL Editores, pp. 315-338.

González, Sergio. 2020. “Agua Santa, espacio pivotante de la industria del nitrato de soda en Tarapacá. Los periodos "peruano" y "chileno" de la oficina más emblemática del ciclo de expansión del salitre", en Revista Interciencia, № 9, vol. 45, Santiago, pp. 434-440.

González, Sergio y Artaza, Pablo. 2013. "El concepto de cantón salitrero y su funcionalidad social, territorial y administrativa: los casos de Zapiga, Lagunas y el Toco”, en González, Sergio. La Sociedad del Salitre. Protagonistas, migraciones, cultura urbana y espacios públicos, Santiago, RIL Editores, pp. 325-365.

González Pizarro, José Antonio. 2017. “La Compañía de Salitres de Antofagasta, Chile. El desafío de su modernización empresarial e innovación estratégica”, en Estudios Atacameños, N 60, San Pedro de Atacama, pp. 133-159.

González Pizarro, José Antonio. 1983. "Breve bosquejo de la pampa y el hombre nortino en la literatura chilena", Anales de literatura hispanoamericana, №12, Madrid, pp. 81-97. 
Hernández, Roberto. 1930. El Salitre. Resumen histórico desde su descubrimiento y explotación, Valparaíso, Imprenta Fisher Hnos.

Hidalgo, Jorge y González, Soledad. 2019. El testamento de Josef Basilio de la Fuente. Sociedad, riqueza y redes de poder en Tarapacá, siglo XVIII, Antofagasta, Qillqa Ediciones UCN.

Jara, Álvaro. 1973. Chile en 1860. William L. Oliver: un precursor de la fotografía, Santiago, Editorial Universitaria.

Paz Soldán, Mariano F. 1877. Diccionario-Estadístico del Perú, Lima, Imprenta del Estado.

Ojeda Berger, Orietta. 2017. "La antigua Palma y la actual Humberstone. Un complejo patrimonial y un paisaje cultural pampinos", en Tiempo Histórico, № 14, Santiago, pp. 15-36.

Riso Patrón, Francisco. 1890. Diccionario Geográfico de las Provincias de Tacna y Tarapacá, Iquique, Imprenta de La Industria.

Rivero, Francisco. 2013. "El devenir del acontecimiento en la operación historiográfica", en Historia y Grafía, año 21, № 41, Ciudad de México, pp. 43-77.

Sabella, Andrés. 1978. Hombre de cuatro rumbos, Santiago, Editorial Nascimento.

Semper, Erwin y Michels, E. 1908. La industria del salitre en Chile, Santiago, Imprenta Barcelona.

Serrano, Carlos. 2005. "Problemas de contaminación y salud en la época colonial”, en Revista Metallica, $\mathrm{N}^{\circ}$ 5, España, pp. 73-85.

Torres, Alflorino. 2017. Familias fundadoras de Pica y Matilla. Incluye Cumiñalla, La Huayca, Huatacondo, Quillgua y el puerto de El Loa, 1590-2015, Arica, Ediciones Universidad de Tarapacá.

Varios autores. 1900. Antecedentes, escritos y documentos relacionados con el juicio seguido por la familia Falcón y Mary y sus contrapartes, contra D. Matías Granja y D. Hijinio Astoreca ante los tribunales de Iquique, sobre reivindicación de 91 estacas de la salitrera "La Granja" (antes San Rafael), Valparaíso, Litografía e Imprenta Sudamericana.

Williamson, Juan. 1860. Observaciones sobre la industria de la provincia de Tarapacá, Callao, Tipografía de Mariano Gómez y $\mathrm{C}^{\circ}$.

Zolezzi, Mario 1993. "Pampa del tamarugal. La destrucción del monte de la soledad (ciclo salitrero)", en Revista Camanchaca, $\mathrm{N}^{\circ} 14$, Iquique, pp. 6-8.

\section{Fuentes}

Archivo DIBAM Regional Tarapacá. Archivo Sernageomin. ARTSNGM

Archivo Notarios de Tarapacá. ANT.

El Comercio de Iquique, 1874 y siguientes.

El Mercurio de Tarapacá, 1861 y siguientes.

El Mercurio de Iquique, 1870. 